\title{
Gran Pajatén y su CONTEXto en el PAisaje PREhispánico Pataz-Abiseo
}

\author{
Warren B. Church ${ }^{\mathrm{a}}$ y Luis Valle Álvarez ${ }^{\mathrm{b}}$
}

\begin{abstract}
Resumen
Desde hace más de cien años, los arqueólogos han atribuido los impresionantes asentamientos monumentales de los bosques montanos de Chachapoyas a intrusiones poblacionales desde regiones vecinas durante épocas prehispánicas tardias, o a la colonización de parte de estados o imperios de la sierra. La longevidad y la tenacidad de estas explicaciones basadas en procesos de migración es extraordinaria, dado el colapso de la popularidad de modelos de la verticalidad y de la presión poblacional que todavía se emplean para sostenerlas. Datos arqueológicos procedentes de Gran Pajatén y de otros sitios del Parque Nacional Río Abiseo, en la parte sur de Chachapoyas, respaldan una interpretación contraria, atestiguando al desarrollo autóctono de sociedades autónomas. Para demostrar los defectos de las hipótesis de migración y la colonización, hemos realizado un reconocimiento arqueológico en la sierra de Pataz, colindante a los bosques nublados donde se ubica Gran Pajatén (2850 msnm), con la finalidad de ubicar y documentar evidencias de las densas poblaciones, centralizadas y supuestamente capaces de desarrollar y subvencionar colonias de monumentalidad y carácter singular. Sin embargo, nuestro reconocimiento solo registró una predominancia de asentamientos pequeños y dispersos en la sierra, un resultado que contradice las expectativas de los modelos de migración. Otra meta de nuestro reconocimiento fue emprender el reto de colocar a los sitios del área Pataz-Abiseo dentro de un contexto mayor de desarrollo demográfico. La abundancia de asentamientos pequeños en la sierra relacionados a una infraestructura de transporte y comunicación, junto a una red de caminos, nos permite plantear que un flujo dinámico de viajeros, y una intensa interacción interregional, promovieron el proceso de nucleación poblacional y la construcción de asentamientos permanentes dentro del bosque. Los contactos mantenidos con una diversidad de regiones habrían impulsado innovaciones locales que culminaron en logros estéticos únicos como Gran Pajatén, y otros sitios monumentales dentro de los bosques montanos de la ceja de selva en el Parque Nacional del Río Abiseo, denominado Patrimonio Cultural del Mundo por Unesco desde 1991.
\end{abstract}

Palabras clave: arqueología, Chachapoyas, Gran Pajatén, ceja de selva, bosque montano, demografía, cronología, interacción, movilidad, paisaje, Abiseo

\section{Abstract}

\section{GRAN PAJATÉN AND ITS CONTEXT IN THE PRE-HISPANIC PATAZ-ABISEO LANDSCAPE}

For more than one hundred years, archaeologists have attributed impressive monumental settlement complexes in the tropical montane forests of Chachapoyas to late pre-Hispanic population intrusions from neighboring regions, or to colonization by highland states and empires. The longevity and tenacity of these migrationist explanations is remarkable given the virtual obsolescence of verticality and population pressure models still invoked to support them. Archaeological data from Gran Pajatén and other sites in the Río Abiseo National Park in the southern part of Chachapoyas support a contrary interpretation, attesting to the autochthonous development of autonomous societies. In order to demonstrate the defects of the most widely-accepted migration and colonization hypotheses, we carried out a reconnaissance in the highlands of Pataz District adjacent to the montane cloud forest where Gran Pajaten $(2850 \mathrm{~m})$ is located, in order

${ }^{a}$ Department of Earth and Space Sciences, Columbus State University

Correo electrónico: church_warren@columbusstate.edu

b Qetzal, S.A.C.

Correo electrónico: siancasadelaluna@yahoo.es 
to locate and document archaeological evidence of dense, centralized populations allegedly capable of launching and subsidizing "colonies" of such monumentality and unique character. However, the reconnaissance only registered a predominance of small and dispersed settlements in the highlands, a result that contradicts the expectations of migration models. An additional goal of our reconnaissance was to begin placing sites of the Pataz-Abiseo area within a broader context of local demographic development. The abundance in the highlands of small sites related to transport and communication infrastructure along the road networks supports the argument that a dynamic flow of travelers and intense interregional interaction spurred processes of population nucleation and the construction of permanent settlements within the forest. Contacts maintained with such a diversity of regions would have driven local innovations culminating in unique aesthetic achievements such as Gran Pajatén and other monumental sites in the montane forests of the Rio Abiseo National Park, designated World Cultural Heritage by UNESCO in 1991.

Keywords: Archaeology, Chachapoyas, Gran Pajatén, tropical montane forest, demography, chronology, interaction, mobility, landscape, Abiseo

\section{Introducción}

De los cuantiosos misterios arqueológicos y sitios enigmáticos del Perú, tal vez la "ciudad perdida" de Gran Pajatén es el que más sigue cautivando la fascinación del público entrando al siglo veintiuno (Fig. 1). Desde su (re)descubrimiento en 1963 - y dos expediciones gubernamentales con estudios científicos en 1965 y 1966 (Rojas Ponce 1966; Pimentel 1967; Bonavia 1968)_, los arqueólogos han ofrecido interpretaciones contradictorias y controvertidas en cuanto al origen, la antigüedad y función no solo de Gran Pajatén, sino de todos los asentamientos monumentales de Chachapoyas y los bosques andinos orientales. Mas que otros sitios atribuidos a los chachapoya, el monumento ha ganado fama mundial por la alta calidad técnica de su arquitectura, la decoración de los edificios principales, mediante frisos con motivos simbólicos y su atracción estética. Luego de las primeras investigaciones, el director de la investigación arqueológica Rojas Ponce (1966: 127) planteó que el monumento pertenecía a la "cultura Huaylas», término clasificatorio concebido por su profesor Julio C. Tello para referir a los moradores de la cuenca alta del Marañón. Poco tiempo después, Duccio Bonavia, arqueólogo acompañante de la expedición en 1966 concluyó que tales sitios del bosque eran colonias compuestas de gentes serranas, colocadas por los inka para facilitar el acceso a productos agrícolas de las tierras bajas (Bonavia y Ravines 1967; Bonavia 1968). La conclusión de Bonavia y Ravines recibió el respaldo de Kauffmann en sus textos del Manual de Arqueologia Peruana $(1976,1983)$, hasta que este planteó su interpretación propia. Kauffmann concluyó que al final del primer milenio d.C. hubo una gran ola migratoria que penetró a los bosques orientales, motivada por presiones demográficas, especialmente una escasez de tierras y alimentos (Kauffmann 1987, 1991). Cabe agregar que estas tres interpretaciones se derivaron de dos campañas gubernamentales muy cortas para "limpiar» y documentar este sitio monumental, las cuales constaron en seis días de trabajo de campo por Bonavia y de una breve visita por Kauffmann, algunos ańos después.

Por una variedad de razones, otros arqueólogos expresaron su desacuerdo con las conclusiones de Bonavia y Kauffmann (v.g. Isbell 1970, 1974; Lumbreras 1974; Raymond 1976; Shady 1976). A pesar de la carencia de consenso académico, la persistencia por parte de Bonavia y Kauffmann en seguir publicando sus interpretaciones, con cambios solo ligeros a través de tres décadas, aseguró la prominencia del «modelo migracionista» en textos sintéticos (en el caso de Bonavia) y en la prensa popular (en el caso de Kauffmann). Según este modelo, la ocupación humana de las vertientes orientales fue resultado de inmigración de poblaciones desde la sierra vecina durante los últimos siglos prehispánicos. Esta resolución de la paradoja de construcciones monumentales, ubicadas dentro de los lejanos bosques nublados, parecía satisfacer a la comunidad académica, tanto como al público. Todo el mundo compartía la suposición «razonable» que nadie quiso vivir en un ambiente tan agreste, empinado y lluvioso como la ceja de selva (referencia geográfica adoptada por Bonavia), 
Figura 1. Mapa del Perú mostrando bosques montanos (ceja de selva) y bosques premontanos de las vertientes orientales andinas y la región de Chachapoyas y el área de estudio "Pataz-Abiseo" (W. Church, adaptado de Young y León 1995).

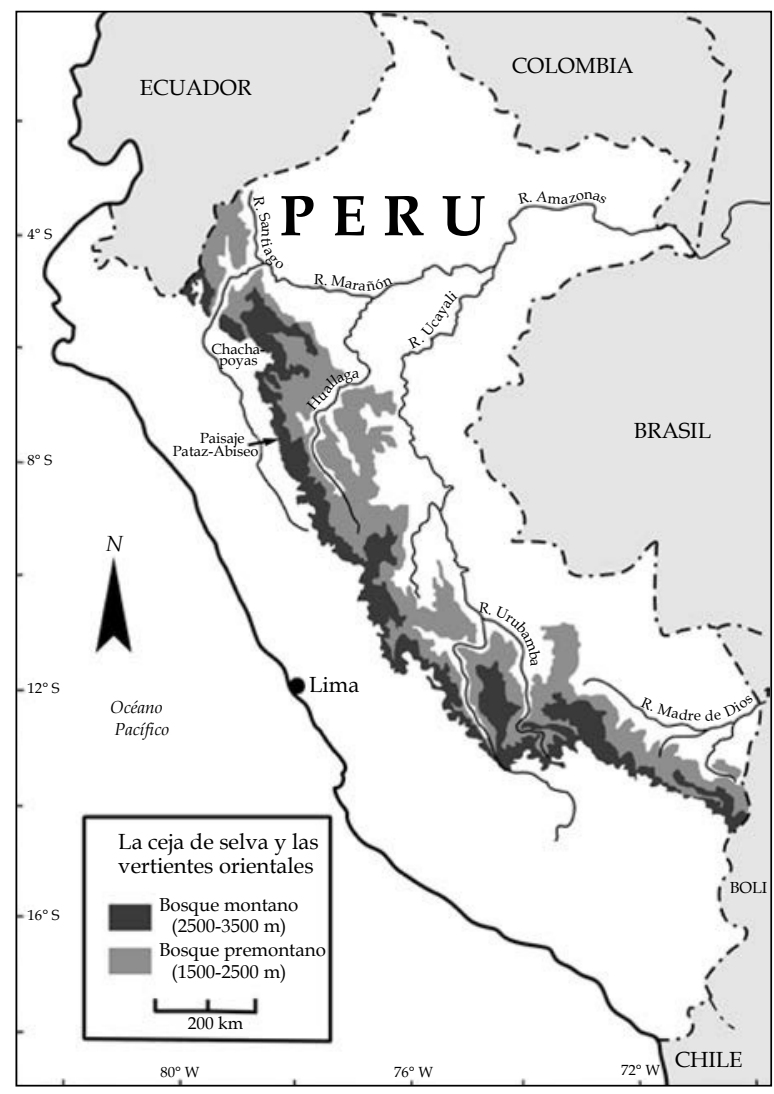

o «los Andes amazónicos» (nombre "geográfico-cultural» planteado por Kauffmann). De hecho, la ceja de selva durante la década de 1960 fue mayormente deshabitada y poco explorada. Los ecologistas y geógrafos calificaron los altos bosques montanos como carentes de utilidad económica (Tosi 1960, ONERN 1976). Es así, que los modelos migracionistas resultaron convenientes para explicar el origen de las poblaciones y la antigüedad de los monumentos que, de otra manera, se hubiera considerado como anómalos.

No obstante, quedó sin solución adecuada — y aparentemente de importancia secundaria-, la cuestión de la "función» de Gran Pajatén y de otros sitios encontrados en la ceja de selva. Gran Pajatén ha mantenido su imagen de «enigmático» $\mathrm{y}$ «misterioso» sobre todo por su ubicación actual, alejada de poblaciones e infraestructura moderna. (Figs. 2 y 3). En cuanto a las posibles funciones especializadas económicas o sociopolíticas que ejerció el sitio, aún existen especulaciones de que era una "colonia agrícola-militar» (Bonavia 1968), un centro religioso (Bueno et al. 2009), o un centro administrativo-cultista (Kauffmann 1987). Hasta ahora persisten tales conjeturas sin fundamento porque las interpretaciones más divulgadas siguen representando a Gran Pajatén de forma irrealista y descontextualizada, como si nunca hubiera tenido un lugar ni papel dentro del sistema de asentamientos local y regional. Desde las investigaciones de Bandelier (1907), toda la región de Chachapoyas ha sido percibida como eternamente remota y desconectada del resto del mundo andino por la «barrera» imaginaria del cañón del río Marañón. Kauffmann informa sobre algunos sitios alrededor de Gran Pajatén en la cuenca del río Montecristo como La Playa y Las Papayas, sitios que documentaron e investigaron otros arqueólogos. Sin embargo, él representa cada uno como si fuera una pieza de arte estático, sin historia propia, sin gente de carne y hueso que mantenía vinculaciones activas con gentes de todas las regiones vecinas a través de milenios. 


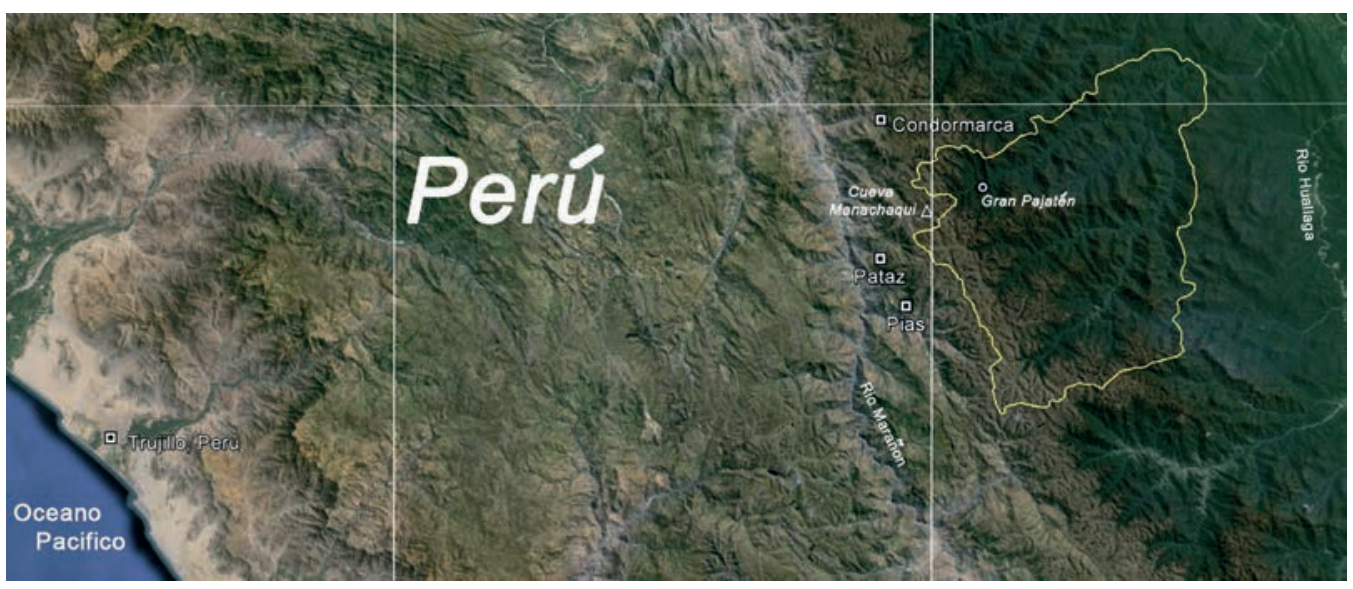

Figura 2. Imagen de satélite mostrando las ubicaciones de sitios arqueológicos, ciudades modernas y el límite del Parque Nacional del Río Abiseo (imagen Google Earth).

Hace más de dos décadas, se difundió evidencia arqueológica de ocupación humana temprana en la ceja de selva, asociada al Pleistoceno Final con una antigüedad de más de 10.000 ańos, excavada de la Cueva Manachaqui (Church 1996, 2004). Excavaciones en Gran Pajatén en 1985 y 1986, descubrieron depósitos culturales con fechas abarcando 400 a.C. (Church 1991, 1997). Si Gran Pajatén no se hubiera encontrado en un lugar remoto como la ceja de selva, habría sido interpretado sobre la base de los datos y no en teorías deterministas solamente.

El sitio Gran Pajatén es un asentamiento extraordinario por el grado de elaboración constructiva y decorativa aplicado en sus cuatro construcciones más prominentes. Bonavia informó de utensilios domésticos excavados dentro del Edificio No. 1. Las evidencias recogidas durante nuestras dos campańas y casi dos meses de investigaciones en Gran Pajatén (1985 y 1986) indican que el edificio fue el domicilio de una(s) persona(s) «de status privilegiado», con los recursos suficientes como para erigir un edificio de tal profusión decorativa (Church 1997: 235). En cuanto a su arquitectura, no hay antecedente como prototipo reconocible en la sierra vecina. Estas interpretaciones alternativas, derivadas a partir de análisis de datos excavados, han sido minimizados e ignorados en las interpretaciones «tradicionales», que se pueden agrupar debajo del término «alóctonas». A consecuencia de las publicaciones que aun propagan las hipótesis «migracionistas», aún durante el siglo XXI (Kauffmann 2009, 2013; Kauffmann y Ligabue 2003), la ceja de selva se adquiere la fama de uno de los últimos bastiones del migracionismo del mundo.

El presente capítulo se dirige a corregir el problema persistente del conocimiento errado del origen y de la naturaleza de Gran Pajatén y de los sitios cercanos dentro del valle del río Montecristo como, La Playa (Deza Rivasplata 1975-76; Cedrón Goicochea 1989) y Los Pinchudos (Kauffmann 1980; Morales et al. 2004), y de la ocupación humana de la región de Chachapoyas, en general. Gran Pajatén siempre ha jugado un papel céntrico en los debates y propuestas explicativas de la arqueología de Chachapoyas y de las vertientes orientales (o ceja de selva). Por lo tanto, es apropiado comenzar nuestra discusión en el mismo sitio. Con la salida de las monedas de un nuevo sol y billetes de 100 nuevos soles grabadas con la fachada del Edificio No. 1 del sitio, y su atribución a la "cultura Chachapoyas» (http://monedasdelperu.com/serie-riqueza-y-orgullo-del-peru/ riqueza-y-orgullo-del-peru-gran-pajaten/), se puede caracterizar al Gran Pajatén ahora como un sitio emblemático de "la cultura Chachapoyas». En este artículo, no solo demostramos con datos arqueológicos que las culturas (y probablemente las poblaciones), responsables por Gran Pajatén representan un desarrollo autóctono y autónomo, sino repetimos las opiniones de otros académicos que las culturas de la región arqueológica-etnohistórica de Chachapoyas tienen raíces profundas en suelo chachapoyano. Con este capítulo ampliamos el contexto cultural del sitio de Gran Pajatén, 


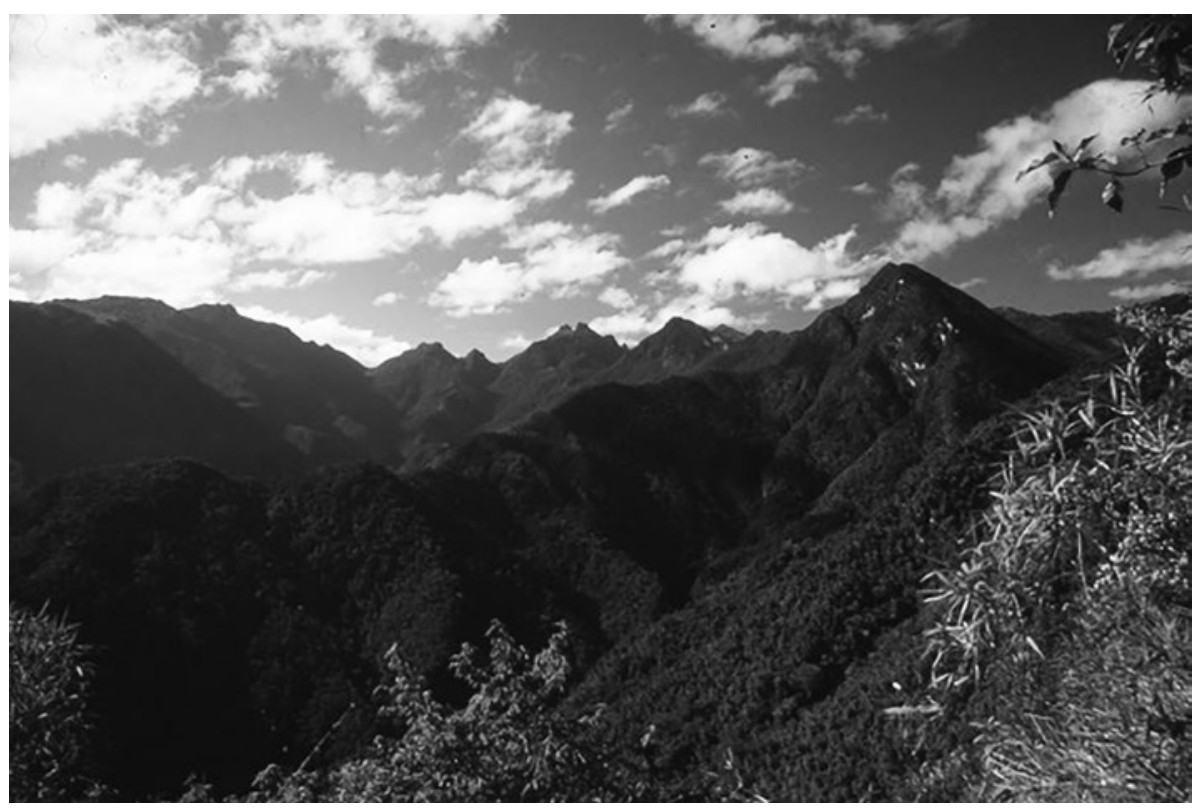

Figura 3. Vista del alto bosque montano tropical en el valle del río Montecristo, Parque Nacional del Río Abiseo (foto de W. B. Church 1985).

intentando «normalizar» a su arqueología mediante la presentación de mayor información sobre la historia del asentamiento antiguo y regiones vecinas.

Antes de proseguir, se debe aclarar un punto de contradicción y posible confusión en la literatura sobre Gran Pajatén y su relación a Chachapoyas inkaico, y luego a Chachapoyas colonial. La filiación cultural de «cultura Huaylas» asignada al sitio por Rojas Ponce ya no es utilizada por los arqueólogos debido el incremento de nuestro conocimiento sobre la diversidad cultural que englobaba. Bonavia por su parte, ni siquiera identificó ninguna filiación cultural conocida para asignar al Gran Pajatén. Sin embargo, en otras publicaciones simultaneas, caracterizó sitios chachapoya del norte dentro de la región arqueológica que él definió como ceja de selva (Bonavia y Ravines 1967). En su monografía sobre Gran Pajatén, Bonavia menciona que consultó con Henri y Paula Reichlen, compararon la alfarería de este sitio con las del alto Utcubamba, y acordaron que los dos estilos no eran lo mismo. Surge una contradicción en el hecho que Bonavia nunca vinculó al Gran Pajatén con la cultura Chacha o Chachapoya, aunque él insistió que Gran Pajatén históricamente fue el mismo sitio identificado como el pueblo Chachapoya de «Yaro» en el mapa y texto de Espinoza Soriano (1967). A simple vista, parece que el mapa de Espinoza estuvo basado en la narrativa de Garcilaso de la Vega (1966 [1609]), pero incluye nombres de localidades en este mapa que no son mencionados por Garcilaso, pero no cita otras fuentes de donde estas habrían sido obtenidas.

En 1990, Bonavia aseveró que los escasos documentos pertenecientes a la región no identifican de modo positivo al sitio de Gran Pajatén: "No sabemos con certeza si los restos del Abiseo [Gran Pajatén] fueron uno de los llacta chacha [asentamientos Chachapoya]» (Bonavia 1990: 260). En su obra sintética sobre la prehistoria andina, Bonavia distinguió las regiones de Chachapoyas y de ceja de selva como dos áreas geográficos-culturales distintas (Bonavia 1991). Luego trató al Gran Pajatén como sitio de la ceja de selva, sin mencionar ninguna relación con Chachapoyas. Durante casi tres décadas desde su redescubrimiento, pocos estudiosos describieron al Gran Pajatén como sitio Chachapoya. Las tesis de Church $(1988,1996)$ describe la filiación del sitio como dentro del entorno de Chachapoyas, descrito por Garcilaso y Espinoza. Fue dentro de la caracterización de Chachapoyas como área cultural, etnográfica, etnohistórica y arqueológica 
presentada por Schjellerup (1997, 2005), que Gran Pajatén fue identificado explícitamente como sitio Chachapoya, a partir de semejanzas en la alfarería. En las publicaciones de Kauffmann, la atribución de Gran Pajatén como sitio Chachapoya fue indicada de modo consistente (Kauffmann 2009, 2013; Kauffmann y Ligabue 2003). La publicación sintética de Church y von Hagen (2008) repitió el vínculo sin cuestionarlo.

El reconocimiento de este proceso historiográfico, pero contemporáneo, y la forma en cómo se incorporó Gran Pajatén a la categoría cultural Chachapoya, ilumina la manera en que se van construyendo categorías de identidad cultural o epónimos, dentro de narrativas históricas y arqueológicas. Según Garcilaso de la Vega la provincia inkaica, y luego la provincia colonial española, se extendieron hacia al límite de La Libertad con Huánuco y el distrito de Huacrachuco. La identidad cultural de "Chachapoya», como se ha manejado ha sido problemática ya por quinientos años o más. La evidencia de que Gran Pajatén tenía relación estrecha con una etnia denominada Chacha o Chachapoya se hace más notoria en las semejanzas arquitectónicas. Sin embargo, hay diferencias bien perceptibles entre las alfarerías de Gran Pajatén y las de los sitios del alto Utcubamba, como ya lo habían notado Bonavia (1968) y Church (1988). Como el conocimiento de la arqueología de Gran Pajatén y de los sitios considerados en este capítulo es producto de teorías y marcos interpretativos enredados sobre Chachapoyas (sensu Kauffmann) y la ceja de selva (sensu Bonavia), tratamos nuestra área de estudio bajo los dos conceptos geográficos-culturales de Chachapoyas, y simultáneamente de la ceja de selva norteña.

\section{Problemática de Gran Pajatén, Chachapoyas, y la ceja de selva peruana}

La historia de la arqueológica de la ceja de selva, desde Chachapoyas a lo largo de los Andes, hasta Bolivia, comenzó a conformarse durante las décadas de 1960 y 1970 (Bonavia y Ravines 1967, 1968; Bonavia 1968; Isbell 1968; Lathrap 1970) cuando los marcos teóricos preferidos incorporaron elementos de la ecología cultural de Steward (1948; 1972[1955]), la economía política andina de Murra (de San Miguel 1964; Murra 1972), y marcos más eclécticos (v.g. Lathrap 1970; Isbell 1974). Dos procesos de movimiento poblacional, a migración a escala de diversas sociedades y la colonización a escala de las comunidades, fueron herramientas de gran utilidad que portaron arqueólogos de la época (Adams et al. 1978). Estos movimientos poblacionales postulados — pero raramente demostrados-, les sirvieron a los arqueólogos que se esforzaron por explicar la presencia de asentamientos como Gran Pajaten y otros en la ceja de selva.

Como se menciona en el capítulo introductorio, la arqueología de Chachapoyas tiene una larga historia de dependencia en la hipótesis migratoria, como el proceso que habría definido el desarrollo cultural en la región. La voz más consistente en la promoción del marco «migracionista» ha sido Kauffmann Doig, arqueólogo que invoca el respaldo de dos marcos teóricos del siglo XIX: la evolución uni-linear de Lewis H. Morgan (Kauffmann 1983: 80-81; Kauffmann et al. 1989) y la antropogeografia de Friedrich Ratzel (Kauffmann 2013). Hoy en día, Kauffmann (2013) y el arqueólogo Koschmieder $(2012,2014)$ concluyen que la arqueología monumental Chachapoya se debe a una inmigración masiva que asimiló o eliminó unas poblaciones subdesarrolladas, o "pre-Chachapoyas», a partir de 800 o 900 d.C. En Chachapoyas, así como en la ceja de selva, estas migraciones hipotéticas han constituido los fundamentos de las interpretaciones sobre la prehistoria, aunque estas descansan en teorías anacrónicas, de dudosa utilidad. Por estas y otras razones, las hipótesis migracionistas no atraen a otros arqueólogos en la actualidad (v.g. Shady Solís 1987; Morales Chocano 1993; Ruiz Estrada 2011[1972]; Guengerich 2014, 2015).

Como se menciona arriba, el problema del estudio de las funciones de sitios como Gran Pajatén, es resultado de una negligencia o descuido, de parte de algunos arqueólogos para reconocer y difundir datos recogidos mediante reconocimientos sistemáticos y rigurosos. Se encuentra el mismo problema en la parte norte de Chachapoyas. Por falta de información disponible sobre las áreas aledańas, el gran monumento de Kuélap ha sido considerado como una fortaleza, una necrópolis 
fortificada, una ciudadela sagrada (Bradley 2005), un granero colosal (Kauffmann 2013), la capital de una organización política estatal (Narváez Vargas 2013), y como la Torre de Babel (Basadre 1892). Desde nuestro punto de vista, las preguntas sobre las funciones de los sitios de la ceja de selva y de los demás bosques montanos de la cordillera nororiental peruana, van a permanecer siempre sin respuestas satisfactorias mientras que se sigua contemplando a los sitios uno por uno, en forma aislada y descontextualizada. Fue para aliviar ese síndrome que Church publicó más información sobre otros sitios del valle del río Montecristo, en los alrededoresde Gran Pajatén, como La Playa (Deza Rivasplata 1975-76; Cedrón Goicochea 1989) y Cerro Central (Lennon et al. 1989), los cuales se incluyen dentro de un concepto, o herramienta crono-espacial, que he denominado? el "paisaje prehispánico Pataz-Abiseo» para rastrear cambios en las ocupaciones de ciertos medioambientes y el desarrollo de sistemas culturales a través de tiempo (Church 1997).

El presente capítulo amplía nuestra visión del paisaje prehispánico Pataz-Abiseo, mediante datos recogidos durante el reconocimiento en la sierra de Pataz en el año 2000. Al mismo tiempo, empleamos los datos del paisaje Pataz-Abiseo ya publicados para poner a prueba las hipótesis de orígenes alóctonos de las poblaciones de Gran Pajatén, y de otros asentamientos al interior y colindantes al bosque. Los arqueólogos Kauffmann y Koschmieder son de la opinión que la evidencia de ocupación temprana ya reportada de la cueva Manachaqui y de Gran Pajatén no es adecuada para caracterizar la arqueología de nuestra área de estudio, y es más ellos califican como defectuosa la secuencia de desarrollo. Como respuesta, aseveramos que sus críticas carecen de sustancia, por no tratar los datos específicos que hemos publicado en detalle. En vez de comentar sobre los datos científicos, ellos descarten las interpretaciones porque no se alinean con sus presuposiciones teóricas relacionadas al determinismo medioambiental. Aquí planteamos que los resultados de nuestro estudio tienen implicancias negativas para las hipótesis que estos autores usan para caracterizar el pasado chachapoyano y la ceja de selva en general.

Los problemas interpretativos sobre la identificación de las funciones de los sitios y los orígenes de poblaciones están entrelazados ya que estos problemas se pueden solucionar con más información sobre contextos demográficos y cambios culturales cronológicos. La tendencia de investigar a cada sitio en forma descontextualizada no sólo dificulta la identificación de sus funciones, sino contribuye a la mistificación de las gentes responsables y obscurece las trayectorias de su desarrollo, sea in situ o exógeno. Aunque Bonavia no continuó con sus labores en Gran Pajatén, observó: «Un centro urbano no es un establecimiento individual y autosuficiente, sino el componente y uno de los puntos neurálgicos de un determinado sistema. Es por esto que todo juicio que se emita, deberá estar en función de este sistema, tomando en cuenta sus características funcionales dentro de un contexto geográfico y sus vinculaciones generales con el resto de los núcleos que componen el sistema» (Bonavia 1968: 74).

Es urgente pues, resolver de una vez la discordancia entre los dos marcos contradictorias sobre orígenes —alóctonos y autóctonos-, ya que cada marco lleva implicaciones distintas y es capaz de impedir o distorsionar nuestra comprensión de la ecología humana, así como la evaluación de procesos culturales dentro de regiones fronterizas, y la comprensión de su importancia durante el florecimiento de la civilización andina sensu lato.

Los resultados de análisis de datos que aquí presentamos nos llevan a concluir que la arqueología de la ceja de selva representa un registro de procesos culturales autogenerados por poblaciones indígenas que se nucleaban y se dispersaban en base de decisiones propias en forma autónoma. Las sociedades de el Gran Pajatén y alrededor en el valle del río Montecristo construyeron asentamientos y tumbas monumentales, interactuaron con sociedades vecinas de modo autónomo, poseían su prehistoria propia de valor intrínseco, y es muy probable que en momentos claves jugaran papeles significativos en los procesos de desarrollo regionales e interregionales. Sobre todo, nos parece que ninguna solución a las interrogantes ¿Qué era el Gran Pajatén? o ¿Quién construyó el Gran Pajatén? van a resultar convincentes sin que primero se pongan a prueba las hipótesis postuladas para ver cómo resisten análisis rigurosos con datos arqueológicos, no solo en el sitio de Gran Pajatén, sino de sitios y contextos arqueológicos alrededor. El empleo del marco metodológico del 


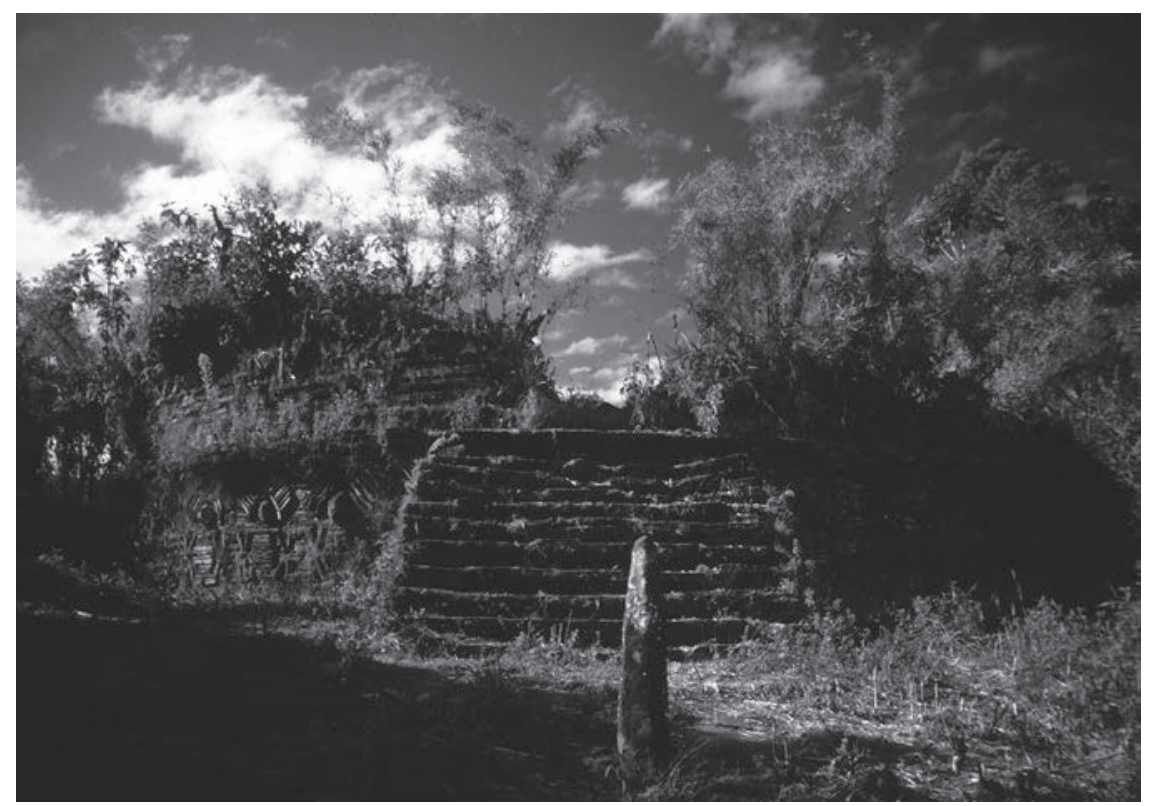

Figura 4. Vista frontal del Edificio 1, Gran Pajatén (foto de W. B. Church 1985).

«paisaje cultural» se describe como una manera apropiada para hacer resaltar las relaciones entre los asentamientos, los caminos, los campos agrícolas, los cementerios y otros sitios que juntos integraron los sistemas socioeconómicos locales y regionales a través de los siglos prehispánicos (Church 1997; Lennon 1992). Por otra parte, este marco sirve de reto para reconstruir la historia cultural alrededor del ámbito del Parque Nacional Río Abiseo y hacer hincapié a las relaciones dinámicas entre los procesos históricos y los contextos paleoecológicos.

\section{Un vistazo al «área cultural» de Chachapoyas (c. 1000 - 1470 d.C.)}

Como se informó en el capítulo introductorio, la tradición arqueológica o cultural que llamamos "Chachapoya» comenzó a florar antes del año 1000, perdurando hasta la conquista Inka alrededor del año 1470. Se distingue por edificios circulares de piedra que se agrupan en los promontorios asociados a sistemas extensos de terrazas agrícolas. Algunos tienen obras defensivas como zanjas o muros perimetrales. Existen sitios excepcionales como Kuélap, Olán y La Joya, con más de 400 habitaciones circulares, algunas con gradas que conectan terrazas y dan acceso a plataformas. Los edificios más prominentes en algunos sitios están adornados con frisos de piedra ejecutados como mosaicos mostrando motivos geométricos y abstractos. Con menos de 30 recintos circulares a $2850 \mathrm{msnm}$, el asentamiento de Gran Pajatén es relativamente pequeńo, pero ha adquirido reconocimiento mundial por la gran variedad de motivos antropomorfos y zoomorfos reproducidos en piedras que conforman la mampostería (Fig. 5), y hábilmente combinados con cabezas clavas y lajas talladas de piedra arenisca. Las tradiciones alfareras más comunes de Chachapoyas muestran formas sencillas, a veces decoradas con diseños incisos y modelados. Los trabajos de campo en las tumbas elaboradas de Los Pinchudos (Morales Gamarra et al. 2002) y laguna de Los Cóndores (Guillén 2002; von Hagen 2002) recogieron objetos funerarios perecibles que revelan una iconografía rica, distinta y hasta ahora poco conocida. 


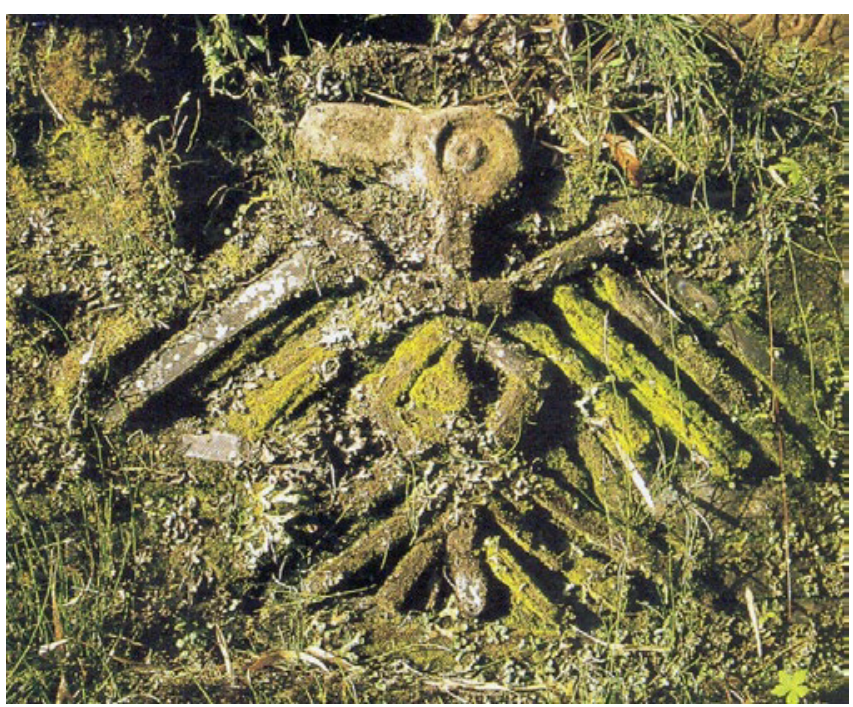

Figura 5. Detalle de friso lítico de ave (tal vez un cóndor) en piedra pizarra dentro de la mampostería del muro externo del Edificio No. 2, Gran Pajatén (foto de W. B. Church 1985).

\section{Hipótesis de considerar}

A continuación, vamos a resumir en forma breve las tres hipótesis que más han invocado los andinistas para caracterizar la prehistoria de la ceja de selva y Chachapoyas. Cabe mencionar que también se ha postulado inmigración procedente de las tierras bajas de Amazonia, pero recién han comenzado proyectos en las planicies del río Marañon (Olivera Núnez 2014), que es zona clave para evaluar dichas hipótesis.

\subsection{Bonavia y la colonización agrícola vertical}

El primero de los tres modelos de la migración que evaluamos se originó en 1966, cuando Bonavia llevó a cabo unas excavaciones en el sitio el Gran Pajatén, en aquel entonces recién dado a conocer públicamente. Bonavia fue influenciado por el modelo ecológico y político de John Murra de la colonización a nivel comunitario (ampliamente conocida como «verticalidad»). Los registros de censo del siglo XVI preparados en varias regiones de los Andes, convencieron a Murra que los habitantes de la sierra — entre ellos, pueblos, reinos, e imperios— había colonizado las faldas bajas de la sierra occidental y oriental para asegurar el acceso a la coca, el maíz, la madera, el algodón y otros productos agrícolas, evitando así la dependencia en el intercambio interregional con pueblos y gentes ajenos. Las excavaciones de Bonavia en Gran Pajatén recuperaron una cantidad significativa de cerámica con influencia inka, lo cual le hizo llegar a la conclusión de que colonos locales de la sierra habían construido este sitio bajo la dirección inka. A pesar del predominio de la cerámica y los estilos arquitectónicos no-inkas, Bonavia concluyó que sólo un estado andino de gran alcance como los inka podría haber subvencionado la colonización sistemática y el asentamiento permanente en Gran Pajatén, y por toda la ceja de selva.

\subsection{Kauffmann Doig y la «serranización de la selva»}

La segunda interpretación notable sobre los orígenes culturales de Chachapoyas, propuesta por Federico Kauffmann Doig, sigue siendo el marco descriptivo dominante en el Perú actual. En 1987, Kauffmann publicó por primera vez su hipótesis, definiendo la «serranización» como una 
migración a nivel de la sociedad desde la sierra hacia los bosques montanos de la ceja de selva y Chachapoyas. Kauffmann interpreta el crecimiento de la población y la creciente necesidad de intensificar la producción agrícola, como el motor que engendró la evolución cultural andina desde sus albores hasta su desbordamiento final, en regiones marginales como la ceja de selva. El término «serranización» se refiere a un proceso mediante el cual Kauffmann cree que los inmigrantes de la sierra deforestaron, y por lo tanto «serranizaron», la vertiente oriental, mientras que estos migrantes adoptaron los rasgos de las culturas amazónicas durante un período de aculturación que empezó alrededor de 800 d.C. En 2013, Kauffmann volvió a publicar otro resumen de su visión de la arqueología de Chachapoyas, pero cambió un detalle: especificó la sierra al oeste del cañón del río Marañon como la fuente de la «cultura Chachapoyas» y no de la sierra de Pataz. Al juzgar por la arquitectura y el material cultural conocido en las áreas correspondientes de Huamachuco y Cajamarca, no hay semejanzas conocidas para sostener su propuesta. Al igual que Bonavia, Kauffmann concluye que los estados poderosos de la sierra se expandieron hacia la ceja de selva, ambos autores señalan al Gran Pajatén para apoyar estas ideas.

\subsection{Crisis medioambiental en la sierra}

Otro grupo de estudiosos de otras disciplinas cita a cambios climáticos como factores desencadenantes o "causas últimas» de: 1) movimientos poblacionales desde la sierra hacia el oriente y 2) el poblamiento de las vertientes orientales. Esta propuesta merece una descripción detallada porque es menos divulgada en el Perú. Lonnie Thompson y su equipo de geólogos (Thompson et al. 1994: 92) proponen que una sequía alrededor de 920 d.C. detectada durante su análisis del registro paleoclimático del glaciar Quelccaya (departamento de Cuzco), habría presentado condiciones medioambientales propicias para el movimiento poblacional hacia el oriente y la proliferación de asentamientos y terrazas de cultivo en la ceja de selva. Sobre las ventajas ofrecidas por los cambios climáticos se menciona solamente: «Durante estos intervalos... [540-610 d.C., 650-730 d.C., y 1040-1490 d.C.]... las precipitaciones reducidas pudieron haber producido condiciones más propicias para la ocupación humana y el sembrado de los cultivos típicos de papas, oca, olluco, quinoa y cañihua» (Thompson et al. 1994: 92; traducción nuestra). Reconocen que unas alteraciones antropogénicas de paisajes regionales pueden haber contribuido a su registro de períodos áridos. Sin embargo, enfatizan la importancia de eventos climáticos no antropogénicos comenzando alrededor de 500, 920, y/o 1100 d.C. Los autores incluso plantean la posibilidad de que los bosques montanos superiores alrededor de Gran Pajatén, no existían antes del presente siglo.

Empleando los mismos datos paleoclimáticos de Thompson, Moseley (1992; 1997: 24; 2001: $72,245)$ propone que una época de sequía desde $\mathrm{AD} 500$ a 900 , que se correlaciona con una expansión agrícola, la construcción de terrazas agrícolas y el «influjo demográfico al área de Kuelap y de los bosques montanos accidentados de Chachapoyas, conocidos como las ruinas de Gran Pajatén» (Moseley, 2001: 258; traducción nuestra). Posteriormente, Moseley (2002: 206) combina los datos paleoclimáticos del lago Titicaca (Abbott et al. 1997) con los del registro de Thompson (et al. 1985) para proponer que una expansión «económica y demográfica», junto con el reclamo de las laderas escarpadas mediante terrazas de cultivo, comenzó a partir de 1100 d.C., para culminar alrededor de 1450 d.C. Según Moseley, un alto grado de movilidad en cuanto a prácticas de subsistencia agro-pastoril caracteriza las poblaciones de la sierra andina y «las sequías fueron catalizadores importantes en la radiación económica y demográfica hacia las cordilleras altas y orientales» (2002: 206, traducción nuestra). Así, las sociedades andinas penetraron en la ceja de selva durante épocas de sequía, para luego retroceder a la sierra cuando el clima volvió a la normalidad. Desde esta perspectiva, la ceja de selva fue un paisaje deshabitado, salvo durante épocas de sequía, cuando sirvió de refugio.

El punto de vista común entre Thompson y Moseley es la atribución a los cambios climáticos de rol catalizador, que impulsó la migración y el poblamiento de los bosques montanos húmedos. Así, los cambios climáticos y medioambientales operaron de deus ex machina para resolver lo que se 
percibe como una anomalía demográfica. Estas hipótesis se asemejan a las perspectivas de Bonavia y Kauffmann, quienes seńalan a la sierra andina como el lugar de poblaciones migrantes, aunque no se esfuercen en identificar a las sociedades supuestamente inmigrantes.

\section{Metas y consideraciones teóricas y metodológicas del estudio}

El presente capítulo presenta un estudio de cambios demográficos regionales mediante el análisis de datos arqueológicos recogidos en la sierra de Pataz con el fin de evaluar la validez de las hipótesis de inmigraciones y orígenes alóctonos. El sitio Gran Pajatén siempre ha figurado como ejemplar por excelencia de un fenómeno pan-andino de presuntas migraciones hacia las vertientes orientales durante los últimos siglos prehispánicos. Todas las hipótesis se fundamentan en la presunción que la ceja de selva era medioambiente mayormente despoblada antes de las migraciones postuladas y, aún más importante para nuestro estudio, que existieron poblaciones grandes por la sierra andina en vísperas de las migraciones propuestas.

\subsection{Migraciones prehispánicas en los Andes y más allá}

Dentro del espacio disponible en este capítulo, no es posible profundizar en aspectos importantes de migraciones y avances en la literatura teórica sobre movimientos poblacionales durante los últimos veinte años, especialmente en los avances en la arqueología del suroeste norteamericano (Cabana y Clark 2011; Cameron 2013). Sin embargo, cabe señalar que la historia de la arqueología andina siempre ha mostrado preocupación sobre la migración como proceso demográfico involucrado en la evolución de la civilización andina. Estudiosos como Uhle (1922), Rivet (1968[1924]), Tello (1921, 1942, 1943), Lathrap (1970) y otros, postularon que el surgimiento de la civilización fue consecuencia de migraciones interregionales de sociedades enteras. Aunque las teorías migracionistas fueron cada vez más rechazadas en los Andes y otras regiones durante la década de 1960, en este momento surge un nuevo interés en un modo de migración netamente andino identificado por John Murra (Murra 1972; Diez de San Miguel et al. 1964). Estas migraciones referidas como "Colonización» de zonas ecológicas escogidas era el componente principal de su modelo Control Vertical de un Máximo de Pisos Ecológicos en la Economía de las Sociedades Andinas (Murra 1972, pero ya formulado en 1964). Actualmente se percibe un paulatino abandono del modelo de «verticalidad». Sobre la identificación arqueológica de una colonia multiétnica dentro del valle Chillón por Dillehay (1979), el mismo investigador admite que la evidencia es «ambivalente» (Dillehay 2013: 295). En los Andes, es probable que los debates sobre los movimientos poblacionales en la ausencia de poderes estatales van a producir una proliferación de modelos más específicos, pertinentes a casos limitados, tales comportamientos demográficos se van a considerar bajo del concepto de la movilidad.

\subsection{Marco teórico y propuestas}

Utilizamos dos herramientas analíticas para evaluar a las tres hipótesis de migración antes mencionados. En primer lugar, hemos aplicado el marco metodológico de concepción amplia de Andrew Chamberlain (2006), el cual denomina la demografía arqueológica. Utilizamos el conteo y las dimensiones de las casas, el tamaño y la estructura de los asentamientos como indicaciones que permiten cuantificar el tamaño y la densidad de las poblaciones, además de rastrear los cambios demográficos. También consideramos los criterios originalmente propuestos por Irving Rouse $(1958,1986)$ para generar expectativas que nos sirvan para evaluar las hipótesis.

5.2.1. Demografía arqueológica. Vale la pena explicar el marco teórico de Chamberlain que sirve de base para el presente estudio. Ya que nuestro problema de investigación se ocupa de la migración humana como acontecimiento histórico común, empleamos el marco teórico de la demografía 
arqueológica en su sentido más amplio para la totalidad de nuestra investigación (Chamberlain 2006). Así como explica Chamberlain (2009), la demografía arqueológica es un marco bastante inclusivo que abarca el estudio del tamaño, la estructura y la distribución de cualquier tipo de población humana a través de espacio y/o tiempo, utilizando una o más clases de evidencias. También asevera que los análisis cuantitativos y cualitativos de atributos específicos de domicilios, asentamientos y artefactos pueden servir de proxies para estimar las densidades y distribuciones relativas (y no absolutas) de poblaciones (Chamberlain 2009). Como tratamos de movimientos poblacionales, sería ideal efectuar un análisis minucioso de muestras osteológicas humanas y marcadores genéticos capaces de informar de las relaciones entre poblaciones y de los orígenes de las poblaciones chachapoya. Las investigaciones en otras regiones andinas por Knudson (2011), Knudson y Blom (2009), Tung (2008) y Sutter y Verano (2006) están bien avanzadas, mientras las investigaciones bioarqueológicas dentro de la región de Chachapoyas, han comenzado recientemente (Gaither et al. 2008; Guevara et al 2016, y este volumen; Nystrom 2006, 2009; Toyne et al. 2017). Entre estos, cabe señalar que el análisis de $\mathrm{ADN}$ de poblaciones contemporáneas de los Andes nororientales del Peru conducido por Guevara et al. (2016) tiene implicaciones importantes para nuestro estudio. Existen marcadores únicos, ni propiamente andinos ni amazónicos dentro del territorio antiguo Chachapoyas. Ya están en marcha estudios parecidos utilizando restos humanos recogidos de contextos arqueológicos de la región. Nuestro estudio se limita a utilizar materiales culturales y sus contextos (proxies) como materia de análisis. Las cifras relativas inferidas mediante reconocimientos y excavaciones dentro de nuestra área de estudio, son adecuadas para evaluar las hipótesis demográficas bajo investigación aquí.

Principalmente, hemos adoptado el marco teórico de la «demografía arqueológica» debido a la simplicidad de su aplicación a datos de grano grueso como son los nuestros. Nuestro marco se toma prestado de la disciplina de la geografía cultural (v.g. Roberts 1996) y de la tradición arqueológica del estudio de «patrones de asentamiento» innovada por Willey en el valle costeño de Virú (1953). Según Willey, tales patrones «reflejan el medio ambiente, el nivel de tecnología de los constructores y las varias instituciones sociales y el control que mantuvo la cultura» (1953: 1; la traducción es nuestra). También tomamos prestado el marco de la arqueología de asentamiento (Trigger 1967: 151) que tiene un enfoque explícito en las relaciones «sociales, económicas y políticas», entre asentamientos y las poblaciones investigadas. Las tres hipótesis de movimiento poblacional que aquí se tratan, son distintas en cuanto a causas, escalas, las condiciones paleoecológicas, la complejidad sociopolítica de los grupos involucrados y las consecuencias culturales en las regiones de origen y de destino. Como marco materialista, la demografía arqueológica empleada así, no es muy útil para discernir motivaciones sociales, ni para comprender el papel de la «agencia» y las agendas de grupos de parentesco o individuos en la toma de decisiones. Aunque este marco sea ecléctico, implementarlo nos permite evaluar a las diversas hipótesis sin adherir suposiciones a priori sobre motivaciones, condiciones, e impactos dentro del área de estudio. Nos obliga examinar a los datos.

5.2.2. Criterios para la identificación de migraciones. Los criterios bien conocidos de Rouse (1958, 1986) han servido a muchos arqueólogos para sostener o refutar casos arqueológicos de migración. $\mathrm{Al}$ reconocer la dificultad de distinguir entre los movimientos de elementos culturales (difusión) y los movimientos de poblaciones (migración), Rouse advocaba la metodología de utilizar «múltiples hipótesis de trabajo» para llegar a inferencias confiables. Ya había advertido que, «No es suficiente suponer que ocurrió una migración y presentar las evidencias que favorecen tal suposición...Se debe considerar y eliminar todas las hipótesis alternativas» (Rouse 1958: 67). Sigue Rouse, "Es responsabilidad de la persona que desee demostrar la ocurrencia de una migración el considerar y eliminar la posibilidad que alguna otra hipótesis mejor acomodaría las evidencias a la mano» (ibid.: 66). Para evaluar cada caso de manera rigorosa, Rouse $(1958,1986)$ presenta un método analítico con cinco criterios explícitos (1958: 64) que son:

1) Identificar a los inmigrantes como unidad intrusa dentro de la región que han penetrado.

2) Rastrear tal unidad hasta su tierra de origen. 
3) Determinar que todas las ocurrencias de tal unidad son contemporáneas.

4) Establecer la existencia de condiciones favorables para la migración.

5) Demostrar que alguna otra hipótesis, como la innovación independiente o difusión de rasgos culturales, no acomode mejor a la evidencia.

Rouse elabora sobre cada criterio, los cuales él considera requisitos para comprobar de modo científico a los movimientos poblacionales prehistóricos. Nosotros los hemos simplificado así:

A. Primero, si Gran Pajatén y otros sitios del valle de Montecristo se originaron a través de la inmigración desde la sierra adyacente, como han planteado Bonavia y Kauffmann, entonces, nuestro reconocimiento de la región de Pataz debe documentar una secuencia que revele un asentamiento denso y nucleado y la presencia de la complejidad sociopolítica antes de la ocupación del valle de Montecristo.

B. Segundo, si una sequía pan-regional impulsó a las migraciones hacia el este desde la sierra central, como plantea Moseley, entonces el registro paleoecológico debe mostrar perturbaciones climáticas que anteceden la aparición de la cultura Chachapoyas, antes de 1000 d.C., como máximo. También se debe observar una reducción general de los bosques.

Antes de profundizar más en los detalles del estudio, cabe señalar que es problemático adoptar la suposición a priori de orígenes migratorios en la ceja de selva, o en cualquier lugar, sin la debida consideración de desarrollo cultural local, de raíces profundas, como es práctica pro forma en otras regiones mundiales. Rouse insistió que la carga de prueba recae en el arqueólogo que postula la migración como explicación de cambio cultural (Rouse 1958). En cuanto a otro aspecto metodológico del problema, Adams y colegas anotan: «Cuando parece que existe una discontinuidad abrupta en la secuencia de desarrollo cultural... hay una tendencia a invocar la migración en lugar de difusión como una explicación, a pesar de que no hay ninguna fuente externa reconocible. Rouse [1958: 65] y Trigger [1965: 40-41] han advertido que tal práctica es empíricamente inaceptable; atributos supuestamente anómalos deben ser trazables a una fuente externa antes de que puedan ser legítimamente considerados como intrusivos» (Adams et al. 1978: 487).

En otras palabras, los arqueólogos deben especificar una sola fuente de la población involucrada mediante el uso de datos arqueológicos en lugar de declarar «desde las tierras altas», o «desde las tierras bajas».

\section{La sierra de Pataz y las zonas medioambientales del área de estudio}

Para evaluar las hipótesis alóctonas, se ha delimitado un área de prospección en forma de cinturón o franja que se extiende con orientación norte-sur colindando y coincidiendo con la cabecera del valle de Montecristo. Geográficamente, el área abarca un rectángulo entre las coordenadas $7^{\circ} 30^{\prime}$ a $7^{\circ} 55^{\prime}$ latitud sur, y $77^{\circ} 25^{\prime}$ a $77^{\circ} 40^{\prime}$ de longitud oeste. Políticamente corresponde a la sierra que comprende la frontera compartida entre la región La Libertad y el Parque Nacional del Río Abiseo (PNRA), Región San Martín. Dentro de La Libertad están los distritos de Condormarca hacia el norte y Pías hacia el sur. Dentro de San Martín el área corresponde a la provincia de Mariscal Cáceres y el distrito de Huicungo. En la Carta Geográfica Nacional (1:100.000) dicha área se ubica en las hojas de Pataz (16h), Bolívar (15h), Jucusbamba (16i) y río Jelache (15i).

El área de prospección cubre las zonas ecológicas por encima de los $2500 \mathrm{msnm}$, omitiendo las cumbres rocosas más altas. Las «zonas de vida» según la clasificación Holdridge corresponden a los bosques montanos húmedos y muy húmedos por debajo y los páramos subalpinos húmedos, muy húmedos y pluviales por encima. Los moradores del pueblo de Pataz (2700 msnm) conocen las zonas cultivadas alrededor como quechua y los altos pajonales por encima como jalca. El límite superior del bosque (que típicamente se varía entre 3400 y $3600 \mathrm{msnm}$ ) se identifica como "puerta de monte». No utilizamos esta etnotaxonomía para evitar la suposición de que las zonas de 
producción modernas siempre coincidían con las del pasado prehispánico. Empleamos la zonificación biogeográfica de Young $(1990,1993)$ para distinguir las macrozonas ecológicas de: 1) zona montano húmedo (2300 a $3400 \mathrm{mnm}$ ) por la cuenca del río Marañon, y 2) zona alpina tropical (3600 a $4300 \mathrm{msnm}$ ) sobre la cumbre divisora entre las cuencas Marañón y Huallaga. Por el lado occidental de la cordillera también existe una franja de bosque enano fragmentado entre los 3400 y 3600 msnm que hemos denominado «transición montano-alpino». Los complejos arqueológicos por la vertiente oriental y la cuenca del río Montecristo (por ejemplo, Gran Pajatén) se encuentran dentro de la zona bosque montano lluvioso (aproximadamente 3600 a $2500 \mathrm{msnm}$ ) o en lengua vernácula, el alto ceja de selva.

Se diseñó el área de prospección para optimizar la probabilidad de registrar aquellos asentamientos prehispánicos de la sierra con la mayor probabilidad de demostrar parentesco históricocultural con los asentamientos y poblaciones de los bosques vecinos. En este sentido, las fronteras del área de estudio fueron ubicadas por conveniencia científica y por lo tanto, deben ser consideradas arbitrarias tiene bordes de conveniencia científica que por lo demás se deben considerar como arbitrarios. El área tiene un ancho promedio de 20 kilómetros, entre la margen derecha del cańón del río Marañón por el lado occidental y el límite superior del bosque por el lado oriental. Tiene un largo de 40 kilómetros, suficiente para incluir las áreas serranas de más alta probabilidad de haber contribuido con los «colonizadores» del valle de Montecristo. La revisión de los documentos históricos indica que las poblaciones indígenas de los valles orientales de los ríos Pajatén, Montecristo y Abiseo, fueron obligados a salir del bosque por el programa virreinal de reducciones (c. 1570 d.C.), y fueron traslados a asentamientos planificados en la sierra, entre ellos "Cunturmarca» $\mathrm{y}$ "Uchupias» (Miranda 1906) que deben corresponder a los pueblos actuales de Condormarca y Pías (Church 1996). Para investigar la demografía prehispánica del Paisaje Pataz-Abiseo, hubiera sido útil referirse a los censos poblacionales presentados dentro de visitas como la Visita de 1572 a la provincia de Chachapoyas, llevada a cabo por Diego Álvarez. Según el etnohistoriador Espinoza Soriano (1967) se ha perdido el documento.

\section{Procedimientos y prospección}

El método más lógico y factible para recoger los datos demográficos propicios para poner a prueba las hipótesis arriba descritas, es la prospección arqueológica de la sierra colindante al bosque montano oriental de la ceja de selva. El objetivo principal de nuestro estudio era buscar asentamientos con restos de muros visibles, aunque se registraron toda clases de sitios arqueológicos. Los asentamientos hipotéticos tan grandes como para haber colonizado el valle de Montecristo deberían de manifestarse de una manera clara en la superficie. Por lo tanto, se utilizaron métodos y técnicas estándares para la prospección y el reconocimiento. Nuestra intención era llegar a una cobertura de $100 \%$ del territorio habitable del área de estudio, pero no fue posible por falta de tiempo y por problemas logísticos de acceso. El reconocimiento se enfocó más en los fondos de los valles y las lomas de los cerros más arriba de $2500 \mathrm{msnm}$, omitiendo las crestas rocosas y los farallones. Dependimos mucho de las entrevistas con gente lugareña que ya conocía íntimamente la zona y sus restos arqueológicos.

Durante los 24 días de prospección, logramos recorrer la mayoría de los fondos de los valles principales y las lomas accesibles durante dos jornadas norte y sur, partiendo de Pataz. Nuestra prospección aprovechó el camino prehispánico Huánuco-Chachapoyas como ruta principal, dando mayor cobertura al lado occidental de la cordillera. Como producto del reconocimiento, se logró documentar 18 sitios arqueológicos, entre ellos asentamientos, tumbas, abrigos rocosos, pictografías, caminos con sitios administrativos y otros sitios sin funciones conocidas. No se ha podido ubicar a todos los sitios arqueológicos de la zona, para lo cual valdría la pena recorrer con mayor intensidad las cabeceras de los valles orientales y los cerros circundantes. En el reconocimiento del valle Los Chochos en 1986, se logró identificar sitios colocados en lugares casi inaccesibles (Lennon 


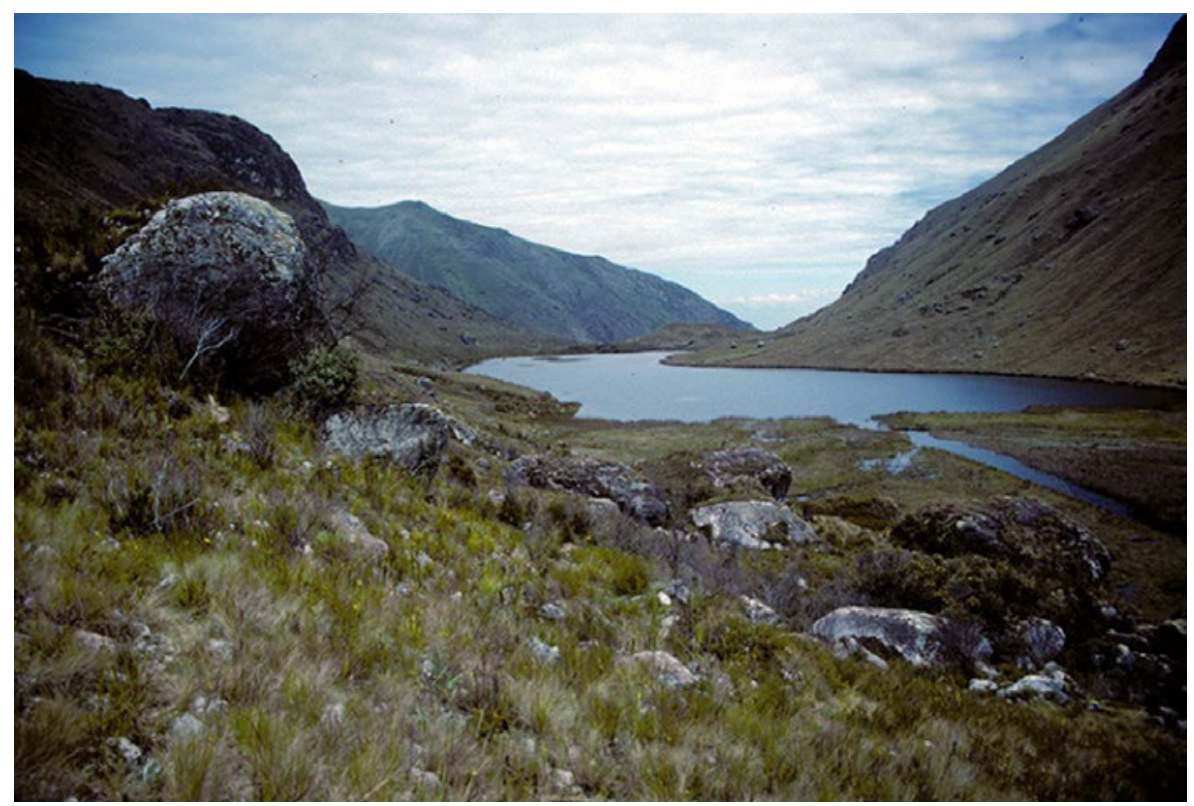

Figura 6. Vista hacia el oeste de abrigo rocoso, Sitio M-7a, valle de Manachaqui, laguna Manachaqui Baja al fondo (foto de W. B. Church 1988).

et al. 1987). Dentro del transcurso de las prospecciones anteriores hemos notado que los sitios pequeños: 1) eran desconocidos a los guías que nos orientaban y 2) se sitúan defensivamente en lugares inhóspitos y de difícil acceso. Por lo tanto, son sitios de funciones especiales que no albergaban poblaciones grandes ni permanentes. También registramos tres sitios reportados por Ravines y Matos (1983) y por Briceńo (2000). Al parecer, ninguno de estos sitios ha sido visitado ni inscrito dentro del registro nacional; no obstante, los tres sitios figuran dentro de nuestro inventario que detallamos más adelante.

\section{Sitios registrados}

En de los párrafos siguientes, se resume las dos etapas de investigaciones que se enfocaron dentro del bosque montano lluvioso y los abrigos rocosos en la zona alpina tropical entre 1985 y 1990, y luego por las zonas alpina tropical y montano húmedo de la sierra colindante, durante el año 2000.

\subsection{Las investigaciones de $1985-1990$}

A mediados de la década de 1980, Church participó en excavaciones en Gran Pajatén patrocinadas por la Universidad de Colorado, y más tarde por la Universidad de Yale. Estas excavaciones confirmaron que los edificios más decorados — documentados primero por arqueólogos peruanos en la década de 1960-, fueron asociados al Período Intermedio Tardío y el Horizonte Tardío. Sin embargo, la excavación adicional en el relleno de construcción debajo del piso produjo fragmentos de cerámica inesperadamente temprana y cinco fechas radiocarbónicas abarcando de 400 a.C. a 500 d.C. En una prospección ampliada en el valle que rodea el de Montecristo se encontraron dos asentamientos, Las Papayas y Cerro Central, que contaron con 100 edificios o más cada uno. En el reconocimiento de la sierra más arriba del bosque, se registró una ausencia de asentamientos, pero las excavaciones de prueba en siete abrigos rocosos (Figs. 6 y 7), incluyendo la cueva Manachaqui (Fig. 8), confirmaron que las zonas altas sobre los $3500 \mathrm{msnm}$ fueron utilizadas 


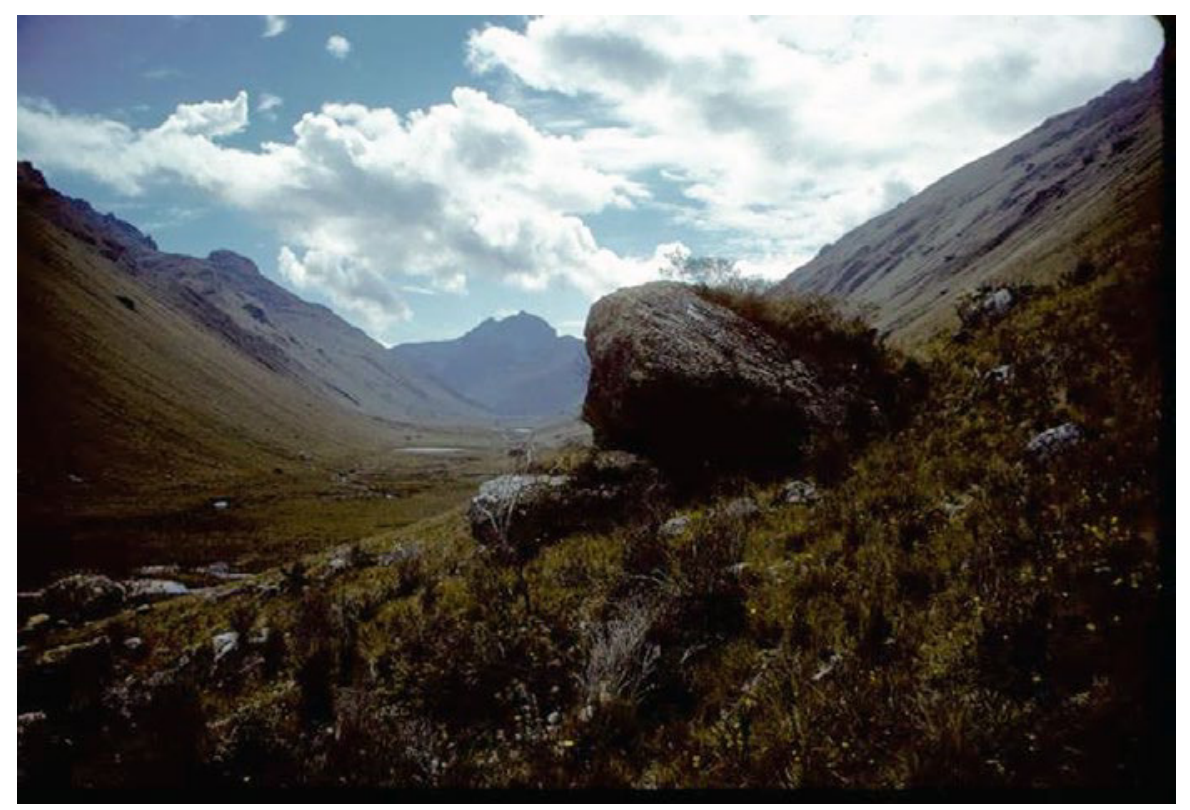

Figura 7. Vista hacia el este de abrigo rocoso, Sitio M-7, valle de Manachaqui (foto de W. B. Church 1988).

desde los tiempos precerámicos hasta el Horizonte Tardío y el período colonial. Los períodos del Precerámico Temprano y Tardío, el Período Inicial, el Horizonte Temprano y el Período Intermedio Temprano fueron los mejor representados. La secuencia estratificada y fechada excavada de la cueva Manachaqui hizo posible fechar los sitios identificados durante la prospección de la sierra de Pataz en 2000.

\subsection{Las investigaciones del año 2000}

La zona de la sierra de Pataz donde realizamos la prospección en el año 2000 se encuentra más arriba de los 2500 msnm y se extiende entre los pueblos modernos de Condormarca y Pías, como mencionamos anteriormente. Fue seleccionada porque el área colinda con $-\mathrm{y}$ encierra - la cabecera del valle de Montecristo, y corresponde geográficamente a los sitios de reducciones de la época de Toledo de mediados del siglo XVI, fundadas para poblaciones extraídas a la fuerza de la selva oriental. Tanto Pías como Condormarca son mencionados por Garcilaso de la Vega como lugares donde las tropas inka se enfrentaron con "pueblos Chachapoyas» durante la invasión y la conquista de Topa Inka Yupanqui (Fig. 9). Nuestro estudio utilizó el camino prehispánico que unen a estos dos pueblos, de modo que nuestra exploración su altamente estratégica. Tras unos 30 días, nos enfocamos en las cimas y otras áreas sugeridas por la topografía, además de localidades con topónimos como «Cerro Las Pircas» y «Cerro Caserones», así como otros que nos fueron indicados por medio de entrevistas con los agricultores locales. Dentro de esta área se documentaron 18 sitios que fueron agrupados en categorías, tres de los cuales son importantes aquí: 1) los asentamientos con arquitectura en pie a una altura promedio de $3400 \mathrm{msnm}$; 2) distribuciones superficiales con tiestos dispersados y puntas de proyectil de pizarra encontradas a la altura promedia de $2800 \mathrm{msnm}$; y 3) las estructuras asociadas con el camino prehispánico (Fig. 10). Las dos primeras categorías sirven principalmente para evaluar las tres hipótesis. Con base en el análisis de la cerámica y la arquitectura de la superficie, se puede asignar cinco asentamientos al período Intermedio Tardío y/o al Horizonte Tardío (Tabla 1). En el segundo grupo, cuatro concentraciones superficiales de tiestos pertenecen a finales del Horizonte Temprano y al Período Intermedio Temprano (Fig. 11). La cerámica en estos últimos sitios se puede correlacionar con los estilos de cerámica más tempranos de Gran Pajatén 


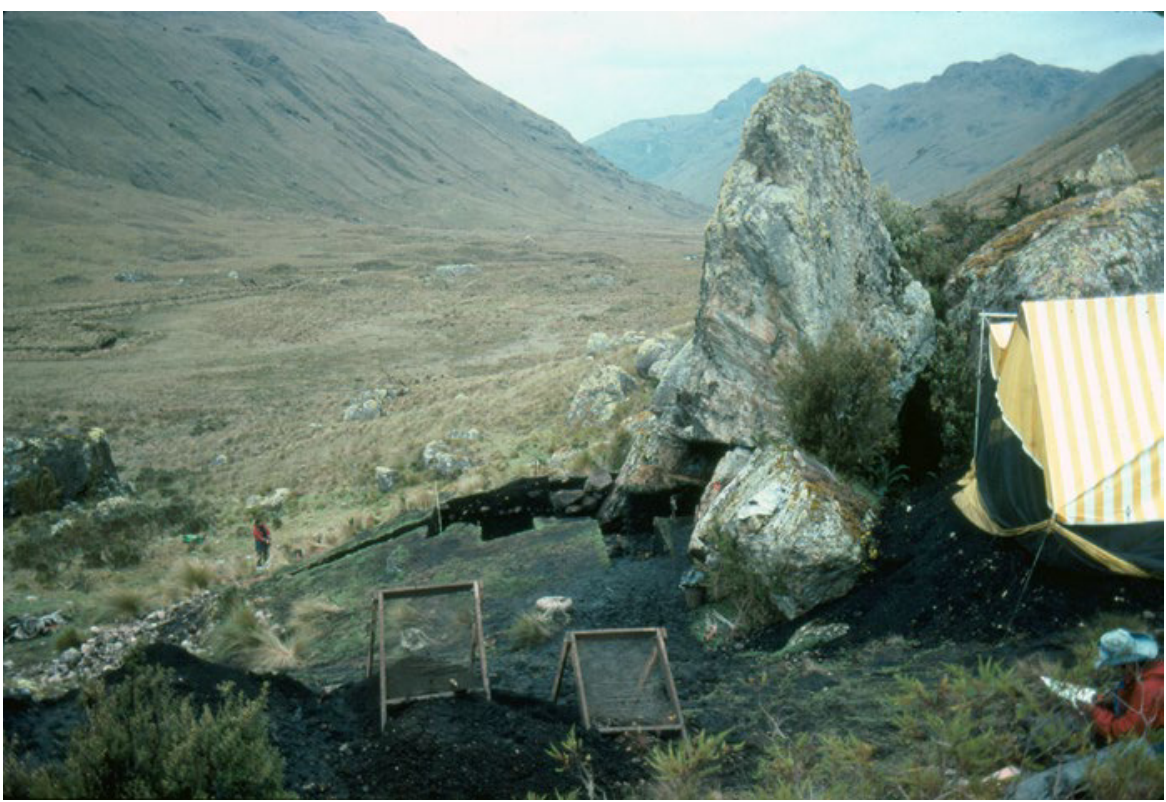

Figura 8. Vista hacia el este de excavaciones en el abrigo rocoso cueva Manachaqui, Sitio M-1 durante campaña de 1990. Camino antiguo apenas visible por la ladera al fondo (foto de W. B. Church 1990).

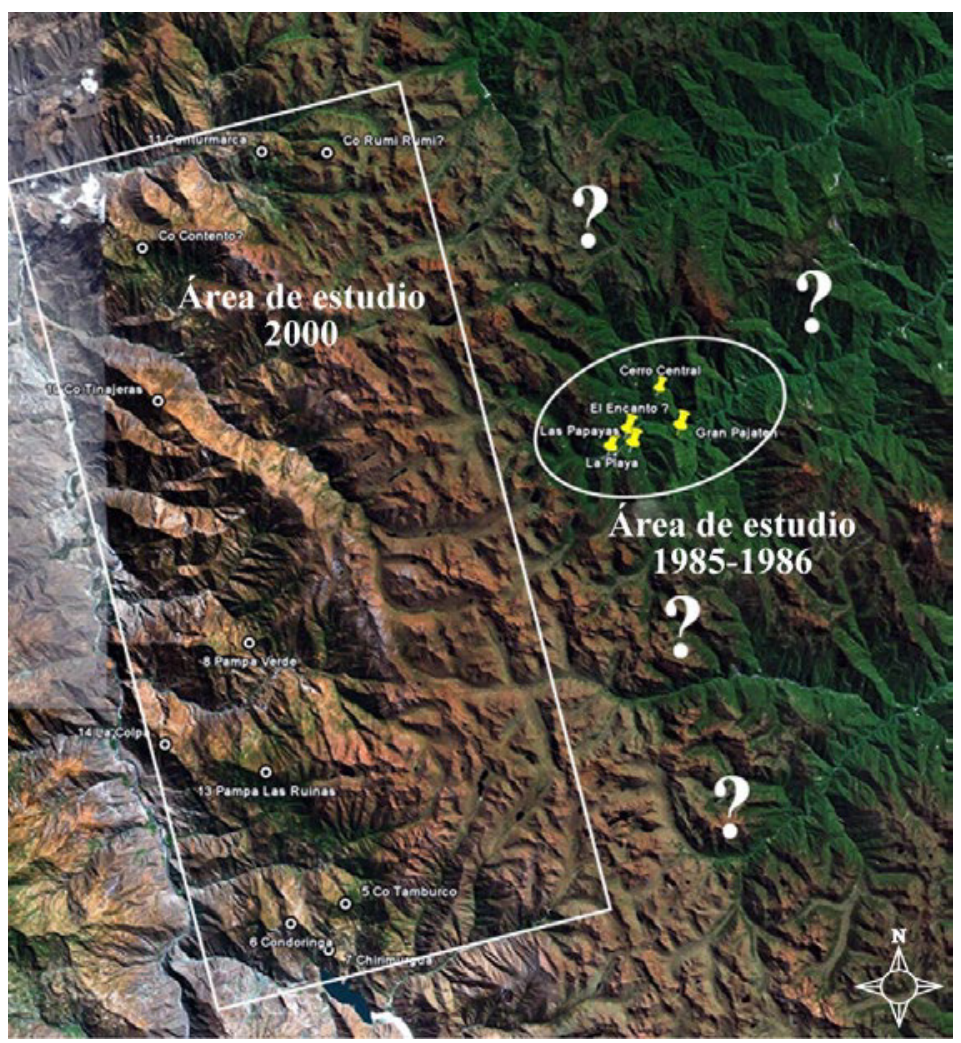

Figura 9. Imagen de satélite mostrando las áreas de estudio durante las campañas 1985-1986 y del año 2000 con algunos sitios arqueológicos indicados (imagen de Google Earth). 

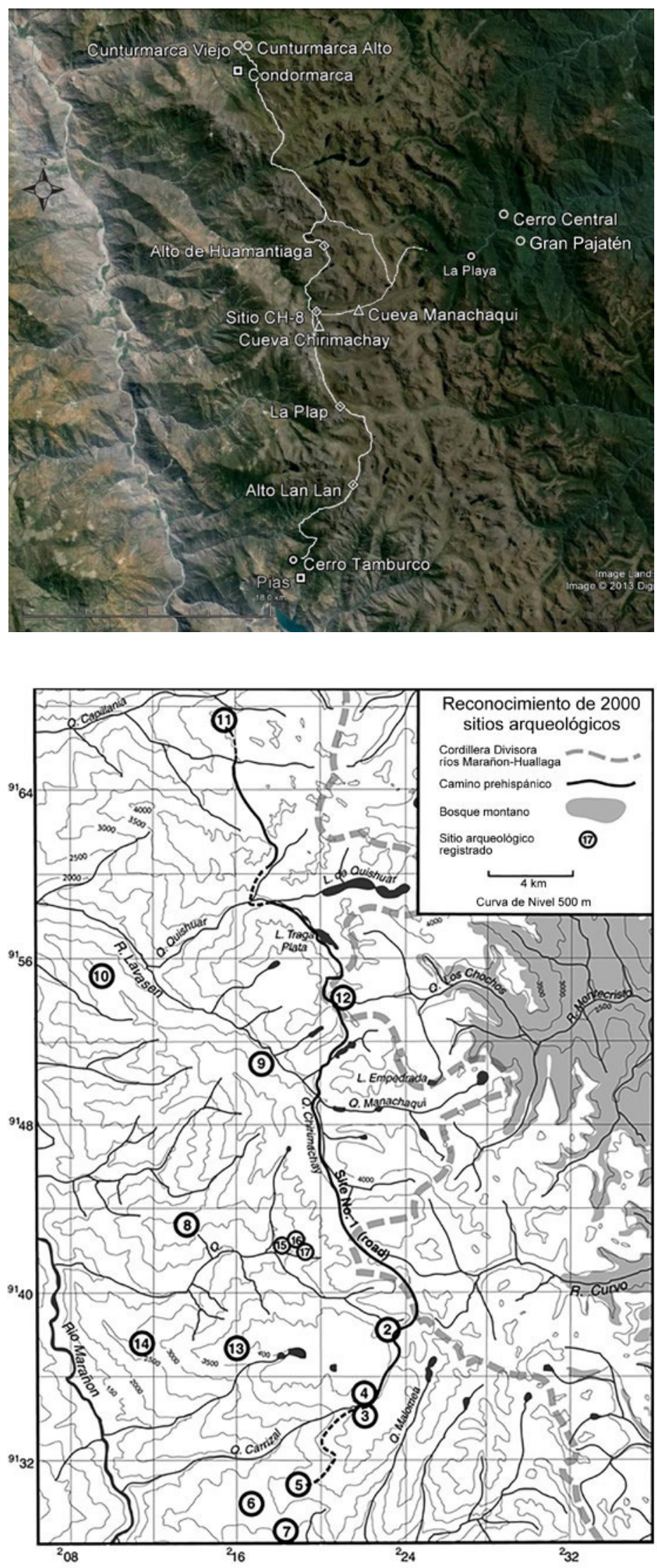

Figura 10. Imagen de satélite mostrando trechos conservados del camino empedrado prehispánico (el Qhapaq Nan), algunas estructuras (o chaskiwasi) asociadas, sitios del valle Montecristo y las ciudades de Condormarca y Pias (cortesia de Google Earth).

Figura 11. Mapa de sitios arqueológicos registrados por los autores durante la campaña del año 2000. 


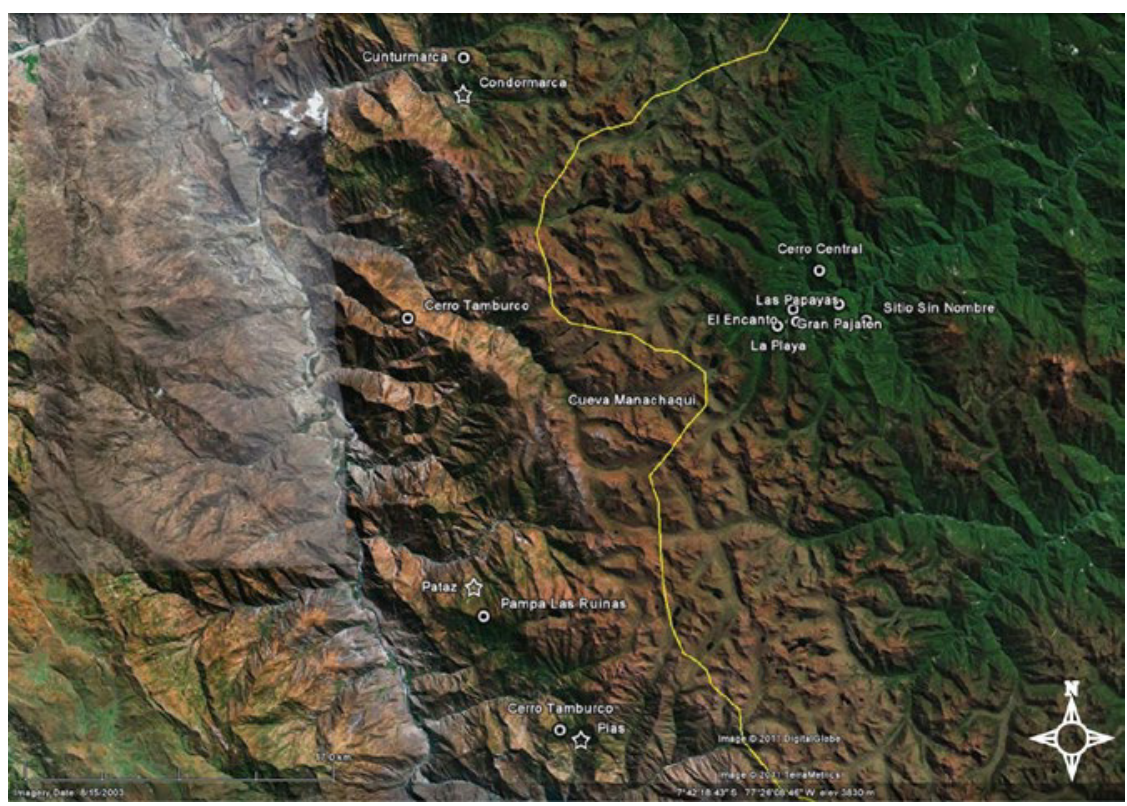

Figura 12. Imagen de satélite mostrando las ubicaciones de sitios arqueológicos del Grupo 1 (tardios), algunas ciudades modernas y el límite del Parque Nacional del Río Abiseo (imagen de Google Earth).

y estilos de la cerámica de la cueva Manachaqui, correspondiente a las fases Suitococha, Colpar y Empedrada. Aunque creemos que el camino empedrado tiene mayor antigüedad, la mayor parte de la infraestructura de los caminos es de construcción y renovación relativamente tardío (Tabla 2).

Entre todos los asentamientos con fechas tardías (Fig. 12), Pueblo Viejo de Condormarca era el único sitio verdaderamente monumental (Figs. 13 y 14). Al juzgar por la arquitectura y el plano del sito, Pueblo Viejo fue construido bajo control Inka, lo cual sugiere que no fue una de las localidades conquistadas enumeradas por Garcilaso de la Vega. Observamos una escasez de decoración inka o local en la cerámica recogida de la superficie. Debido a que el sitio está siendo cultivado intensamente, menos de 50 edificios (de un total de aproximadamente 100) permanecen en pie. Cerro Tinajeras tiene más de 80 edificios circulares (Fig. 15), pero se encuentran dispersos a lo largo de la cresta de una loma y el sitio carece de un núcleo claro. Los vestigios de las paredes de las construcciones circulares de este lugar y las construcciones rústicas en Cerro Alto Las Pircas, raramente se elevan más de 60 centímetros (Fig. 16), sospechamos que eran las bases para paredes de adobe o bahareque.

Tuvimos grandes expectativas de encontrar un sitio monumental arriba de Pías, donde los aldeanos refieren están las ruinas locales en el Cerro Tamburco (Fig. 17). Pero este sitio fue sorprendentemente pequeño y su núcleo demasiado cubierto por la vegetación para producir un buen mapa de un complejo pequeño de edificios circulares, encerrados por un muro tardío. Una leyenda local en Pías cuenta que hace mucho tiempo un gran pueblo cayó en la disolución y la borrachería, y una noche de lluvia Dios castigó a sus residentes, lanzando todo el pueblo hacia abajo por la ladera de la montaña (Paz Esquerre 1990). Esto nos hace preguntarnos si los restos de Pueblo Viejo de Pías se encuentran dentro de la presa natural que contiene la actual laguna de Pías (Fig. 18).

Los sitios arqueológicos encontrados en 2000 y asignado al Grupo 2 consistieron en dispersiones en la superficie de fragmentos de cerámica y puntas de pizarra labrada (Fig. 19). Típicamente los sitios se encuentran en promontorios más arriba del cañón del río Marañón en altitudes entre 2600 y $3100 \mathrm{msnm}$, con un promedio de aproximadamente 600 metros de altura debajo de los sitios del Grupo 1. Se observaron pocas evidencias de arquitectura en la superficie, aunque casi todos estos lugares fueron cultivados y había una abundancia de piedras amontonadas, que pueden haber 


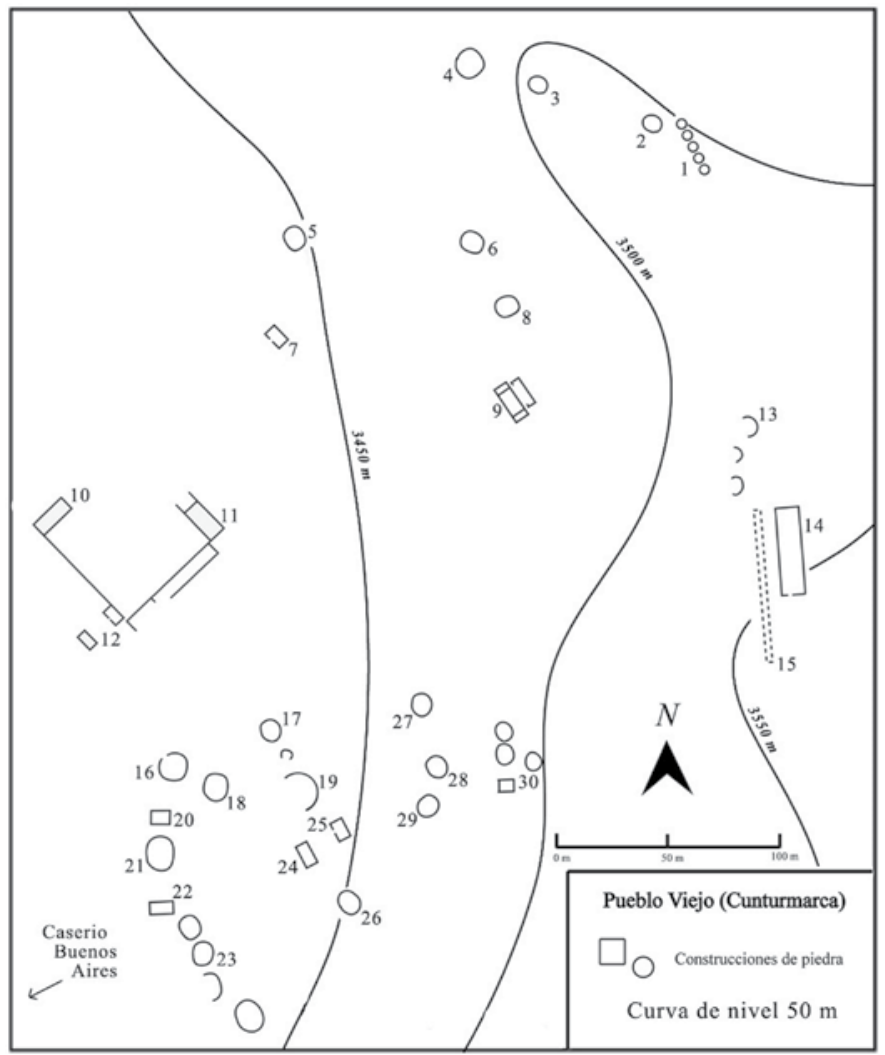

Figura 13. Croquis de restos del sitio de Cunturmarca Viejo, ejecutado en el año 2000 con brújula y GPS de mano (W. Church y L. Valle).

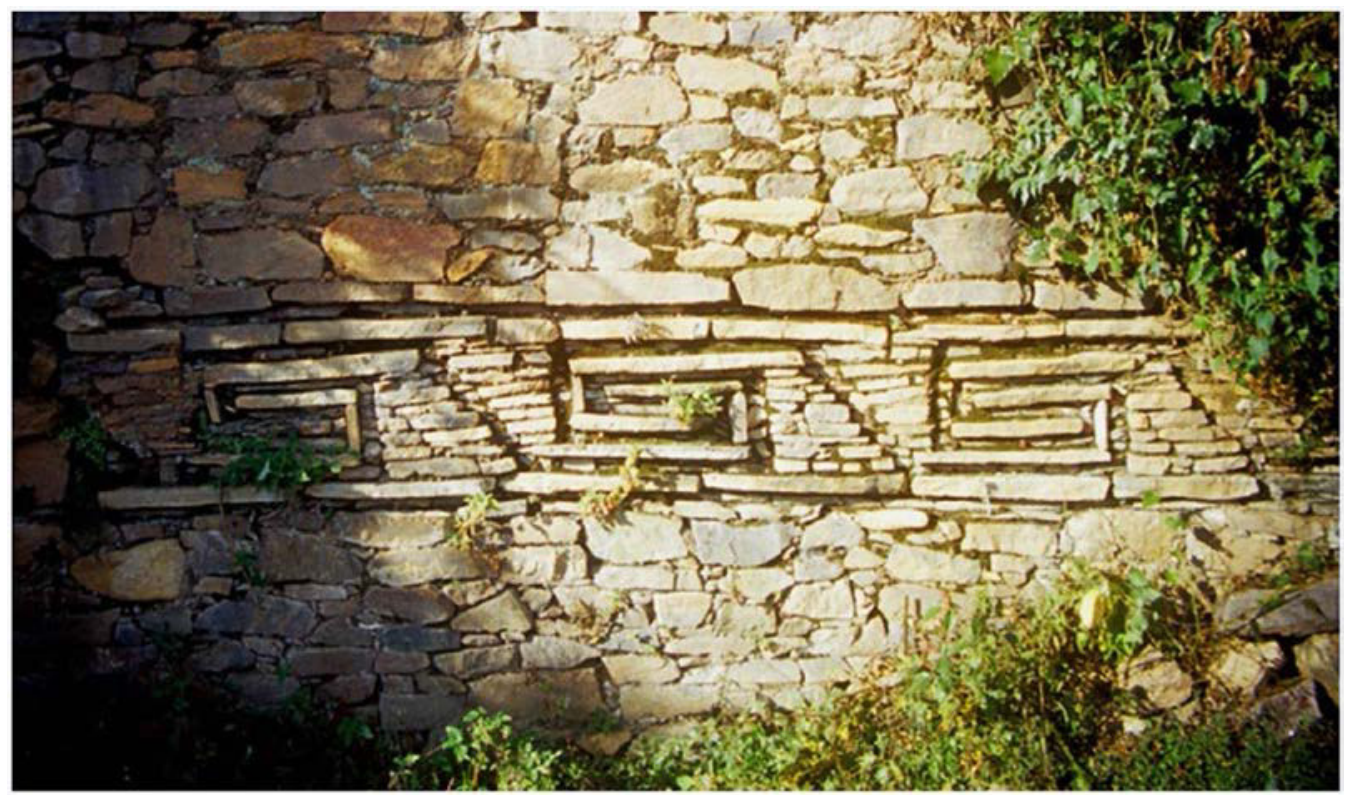

Figura 14. Vista de friso lítico de piedra pizarra con motivo de greca escalonada que rodea superficie interna de muro semicircular, Estructura 19 (foto de W. B. Church 2000). 
Figura 15. Croquis de restos del sitio de Cerro Tinajeras ejecutado en el año 2000 con bríjula y GPS de mano (W. Church y L. Valle).

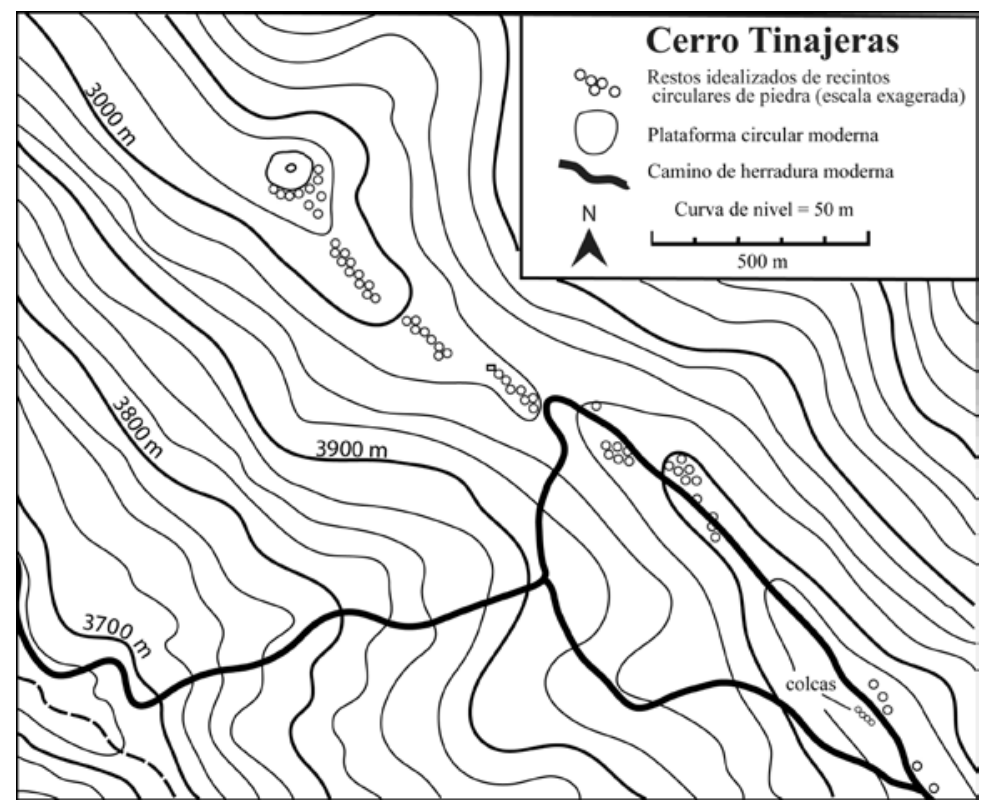

formado la mampostería en algún momento anterior. Las formas de las vasijas, los fragmentos de tazones de caolín con pintura precocción y unos tiestos con decoración incisa, se asemejan mucho a la cerámica de los finales del Horizonte Temprano y a la del Período Intermedio Temprano, recuperadas de la cueva Manachaqui y del Gran Pajatén (Figs. 20-23).

\subsection{Un vistazo posterior por medio de imágenes de satélite}

A partir del año 2010, el programa internet de Google Earth comenzó a agregar imágenes de alta resolución que correspondía a nuestra área de estudio. Durante el 2016, Church hizo un repaso minucioso del territorio con cobertura, que complementan a nuestras observaciones del reconocimiento original, pero no dieron motivo para cambiar el análisis estadístico, ni las conclusiones. Nos sorprendió darnos cuenta que existe otro sitio a solo medio kilómetro rumbo al este y 250 metros más arriba de Pueblo Viejo de Condormarca. A 3675 msnm, el sitio que referimos como Cunturmarca Alto tiene forma ovoide y parece ser un pequeńo asentamiento o refugio defendido por un muro por el lado este, y muros o terrazas por el lado oeste. Se ubica a las coordinadas: $7^{\circ} 31^{\prime} 39.12^{\prime \prime}$ latitud sur y $77^{\circ} 34^{\prime} 54.28^{\prime \prime}$ longitud oeste. Mediante el uso de las imagines, se determinó que el núcleo del sitio mide 135 metros de norte-sur, 90 metros de ancho, y su área cubre 1,25 hectáreas. Aunque la imagen es borrosa, se estima una cantidad de 30 estructuras circulares que puede haber servido de domicilios. Así, se suman 18 sitios arqueológicos que se pueden considerar para el presente estudio. Como se ubica en la cresta de una colina en medio del valle, la vista panorámica desde Cunturmarca Alto debía haber sido estratégica en tiempos de conflicto. De aquí hacia el norte se encuentran otros sitios afuera de nuestra área de estudio.

Otro hallazgo hecho por medio de las imágenes de satélite fue la mayor extensión del sitio Cerro Alto Las Pircas. Debido a que atardeció, no pudimos legar al núcleo del sitio que estaba 300 metros más arriba, a $3871 \mathrm{msnm}$, con coordinadas: $7^{\circ} 48^{\prime} 5.51^{\prime}$ latitud sur y $77^{\circ} 35^{\prime} 0.30^{\prime}$ " longitud oeste. Las estructuras extienden unos 400 metros este a oeste, siguiendo la forma de la loma. Dentro del núcleo se divisan alrededor de 20 a 30 edificios de forma circular. Nuestro cálculo inicial de domicilios en el sitio estuvo muy conservador con una cifra de 100 edificios, así que esta información adicional tampoco afecta el análisis aquí. Al igual que el sitio de Cunturmarca Alto, el sitio de Cerro Alto Las Pircas tiene aspectos defensivos y estratégicos. 


\begin{tabular}{|c|c|c|c|c|}
\hline No. & Nombre & Altura (msnm) & Medio ambiente & Período \\
\hline \multicolumn{5}{|c|}{ Grupo 1} \\
\hline 5 & Tamburco & 3419 & TMA & PITa-HTa \\
\hline 8 & Pampa Verde & 3277 & MHT & PITa-HTa \\
\hline 11 & Cunturmarca & 3490 & TMA & HTa \\
\hline 13 & Cerro Alto Las Pircas & 3830 & ZAT & $\mathrm{HTa}$ \\
\hline \multirow[t]{2}{*}{$10 \mathrm{a}$} & Co. Tinajeras I-III & 3105 & MHT & PITa-HTa \\
\hline & Altura promedio & 3424.2 & & \\
\hline \multicolumn{5}{|c|}{ Grupo 2} \\
\hline 6 & Condoringa & 2920 & MHT & HTe-PITe \\
\hline 7 & Chirimurgua & 2610 & MHT & HTe-PITe \\
\hline $10 \mathrm{~b}$ & Co. Tinajeras IV-VI & 3105 & MHT & HTe-PITe \\
\hline 14 & La Colpa & 2624 & MHT & HTe-PITe \\
\hline & Altura promedio & 2814.75 & & \\
\hline PITa-HTa & \multicolumn{4}{|c|}{ Período Intermedio Tardio y/o Horizonte Tardío } \\
\hline HTe-PITe & \multicolumn{4}{|c|}{ Horizonte Temprano y/o Período Intermedio Temprano } \\
\hline HTa & \multicolumn{4}{|c|}{ Horizonte Tardío } \\
\hline TMA & \multicolumn{4}{|c|}{ Zona Transición Montano-Alpino } \\
\hline МHT & \multicolumn{4}{|c|}{ Zona Montano Húmedo Tropical } \\
\hline ZAT & \multicolumn{4}{|c|}{ Zona Alpina Tropical } \\
\hline
\end{tabular}

Tabla 1. Sitios arqueológicos registrados en el año 2000, agrupados en el Grupo 1 tardio y el Grupo 2 temprano.

\section{Consideración de los resultados}

Nuestro reconocimiento de la región Pataz no llegó ubicar ningún asentamiento nucleado denso, ni ninguna evidencia de complejidad sociopolítica entre poblaciones que tal vez vivieron en aldeas dispersas durante épocas tardías. Utilizamos conteos de casas que en los Andes típicamente albergaron un tributario y una familia de cinco o seis personas (Earle et al. 1987). Es bien posible que había casas deshabitadas o casas con membresías atípicas, como resultado de las epidemias y manipulaciones demográficas por los encomenderos españoles durante el siglo XVI; sin embargo, es muy difícil controlar tales variables. Igualmente, en la selva es difícil recoger conteos precisos de domicilios tapados con maleza. Por consiguiente, tenemos que comparar conteos de individuos, o conteos de habitaciones, y aun así habría fuentes de error en las dos situaciones, pero mezclar las categorías de conteos invalidaría nuestro análisis. En cuanto a domicilios, se contaron un número sorprendentemente bajo de aproximadamente 500 estructuras calificadas como restos de casas para toda nuestra área de estudio de la montańa, lo cual se puede comparar con los aproximadamente 350 recintos circulares registradas en los bosques del valle de Montecristo. Sobre la base de la consideración de estas dos muestras, y con pleno reconocimiento de que el área cubierta en esta prospección del bosque era pequeña comparado al área de cubertura en la sierra, nos encontramos con una proporción de 5 casas de la sierra a 3,5 casas en el valle de Montecristo (Tabla 3). Una proporción de menos de dos a uno no es suficiente para sustentar el modelo de colonización sugerido por Bonavia. De hecho, un análisis detallado de los datos de los censos de Huánuco (1562) y de Chucuito (1567), y las interpretaciones de Murra, sugieren la expectativa de una proporción de ochenta tributarios de los pueblos de la sierra, por cada tributario contado en las colonias de los 


\begin{tabular}{|c|c|c|c|c|c|c|c|}
\hline \multicolumn{8}{|c|}{ Asentamientos prehispánicos Pataz-Abiseo (Período Intermedio Tardío y Horizonte Tardío) } \\
\hline Nombre de sitio & Distrito & Altura & $\begin{array}{l}\text { Área } \\
\text { (ha) }\end{array}$ & Tipo de sitio & Habitaciones & $\begin{array}{l}\text { Zona de } \\
\text { vida }\end{array}$ & Cronología \\
\hline \multicolumn{8}{|c|}{ SIERRA DE PATAZ } \\
\hline Cerro Tinajeras & Cunturmarca & $3105 \mathrm{~m}$ & 5.5 & Asentamiento & 100 & MM & EIP, LIP-LH \\
\hline Alto de Cunturmarca & Cunturmarca & $3670 \mathrm{~m}$ & 1.3 & Asentamiento? & 20 & TAZ & LIP-LH? \\
\hline $\begin{array}{l}\text { Pueblo Viejo de } \\
\text { Cunturmarca }\end{array}$ & Cunturmarca & $3490 \mathrm{~m}$ & 15.0 & $\begin{array}{l}\text { Asentamiento/ } \\
\text { Admin. }\end{array}$ & 100 & MAT & $\mathrm{HTa}$ \\
\hline Pampa Verde-El Ushnu & Pataz & $3277 \mathrm{~m}$ & 3.8 & Asentamiento? & $50 \pm$ & MM & EIP,LIP-LH \\
\hline Chacras Ramirez & Pataz & $2854 \mathrm{~m}$ & ? & Asentamiento? & 0 & MM & PI-HTa \\
\hline Cerro Alto Las Pircas & Pataz & $3830 \mathrm{~m}$ & & Asentamiento & $100 \pm$ & TAZ & $\mathrm{HTa}$ \\
\hline Cerro Tamburco & Pias & $3419 \mathrm{~m}$ & 2.7 & Asentamiento & $50-100$ & MAT & PITa-HTa \\
\hline & & & \multicolumn{2}{|c|}{ Total estimado de casas } & 500 & & \\
\hline \multicolumn{8}{|c|}{ VALLE MONTECRISTO } \\
\hline La Playa & Huicungo & $2655 \mathrm{~m}$ & 3 & Asentamiento & $20 \pm$ & MRF & HTa \\
\hline El Encanto & Huicungo & $2650 \mathrm{~m}$ & $?$ & Asentamiento & $15 \pm$ & MRF & $\mathrm{HTa}$ \\
\hline Las Papayas & Huicungo & $2800 \mathrm{~m}$ & $?$ & Asentamiento & $100 \pm$ & MRF & PITa \\
\hline Gran Pajatén & Huicungo & $2850 \mathrm{~m}$ & 2 & Asentamiento & $24-30$ & MRF & \\
\hline Cerro Central & Huicungo & $2800 \mathrm{~m}$ & $?$ & Asentamiento & $150-200$ & MRF & PITa-HTa \\
\hline sin nombre & Huicungo & $2700 \mathrm{~m}$ & $?$ & Asentamiento & $50 ?$ & MRF & PITa-HTa \\
\hline & & & \multicolumn{2}{|c|}{ Estimado total de casas } & 350 & & \\
\hline \multirow{5}{*}{\multicolumn{3}{|c|}{$\begin{array}{l}\text { MM = Zona Montana Húmeda } \\
\text { MAT = Transición Zonas Montana-Alpina } \\
\text { TAZ = Zona Alpina Tropical } \\
\text { MRF = Zona Montana Bosque Lluvioso }\end{array}$}} & \multicolumn{5}{|c|}{ = Período Inicial (1500-900 a.C.) } \\
\hline & & & \multicolumn{5}{|c|}{ HTe $=$ Horizonte Temprano (900-200 a.C.) } \\
\hline & & & \multicolumn{5}{|c|}{ PITe = Período Intermedio Temprano (200 a.C.-700 d.C.) } \\
\hline & & & \multicolumn{5}{|c|}{ PITa $=$ Período Intermedio Tardío (1000-1450 d.C.) } \\
\hline & & & \multicolumn{5}{|c|}{$\mathrm{HTa}=$ Horizonte Tardío (1450-1535 d.C.) } \\
\hline
\end{tabular}

Tabla 2. Asentamientos prehispánicos del paisaje Pataz-Abiseo del Periodo Intermedio Tardío y el Horizonte Tardio).

nativos Chupachu y Yaro de la vertiente oriental. La proporción sugerida para Chucuito, la cual fue más densamente poblada, podría estimarse en 100 o 200 tributarios de la sierra para cada tributario de las colonias distantes de la ceja de selva.

Nuestra evidencia arqueológica de la sierra que indica una baja densidad de población y un patrón disperso de asentamiento, en combinación con la falta de arquitectura monumental pre-Inka e indicios de la centralización político-económica, sirve para socavar las dos propuestas de Bonavia y Kauffmann sobre los supuestos orígenes migratorios del Gran Pajatén. En suma, no hay evidencia arqueológica clara que vincula los orígenes de los pobladores y sitios del Gran Pajatén y del valle de Montecristo, con el desarrollo cultural de la sierra de Pataz. Un dato provocativo que vale la pena de investigar más a fondo es la ausencia casi total en la sierra de cerámica del estilo Abiseo definido por Bonavia y prevalente en el Gran Pajatén. Contrario a muchas expectativas, la densidad de asentamiento, la elaboración arquitectónica, la singularidad de los estilos alfareros y arquitectónicos y la monumentalidad general exhibidas en sitios de la ceja de selva superaron los niveles previstos por las teorías de ambos arqueólogos.

La tercera hipótesis evaluada es la que sugiere que los cambios climáticos y medioambientales funcionaron como catalizador de migraciones hacia el este, hacia los bosques húmedos de la ceja de selva y la región de Chachapoyas (Thompson et al. 1994; Moseley 1992, 1997, 2001, 2002). 


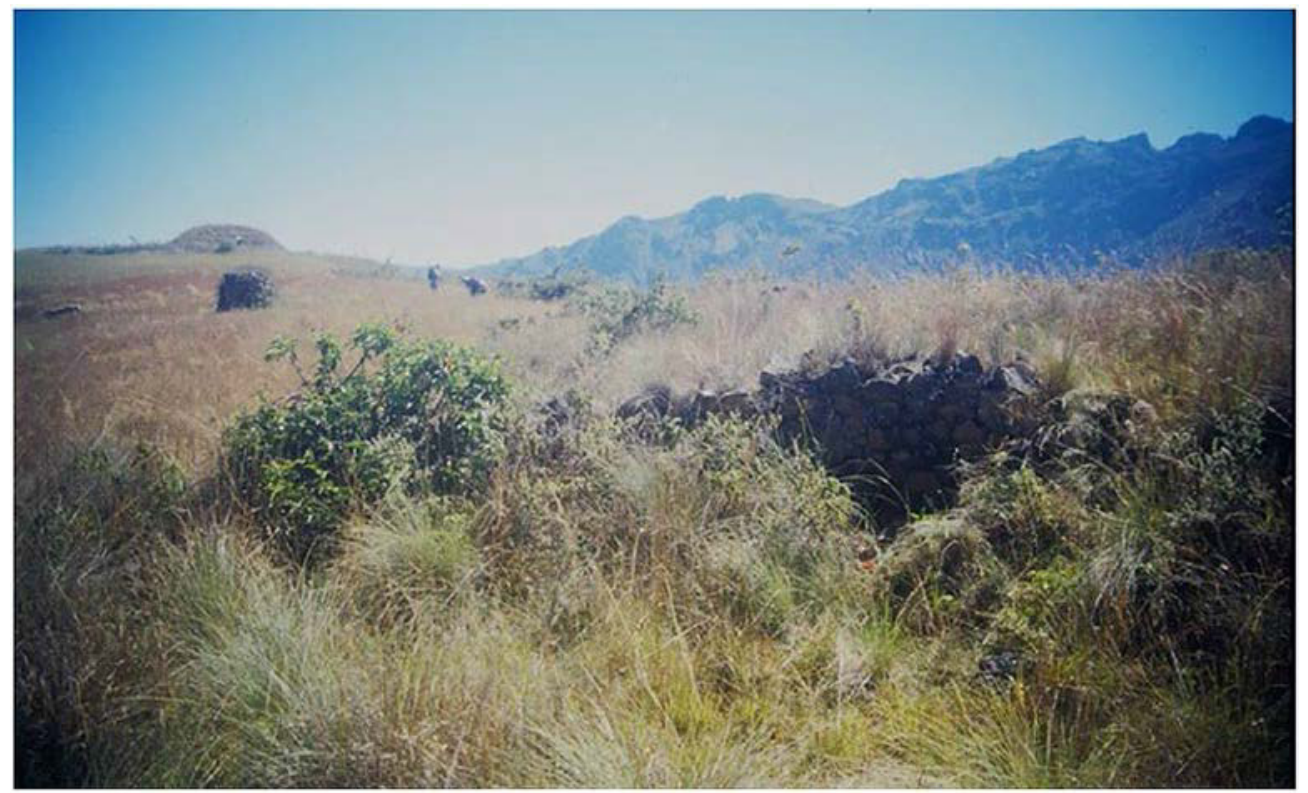

Figura 16. Restos de muro de una estructura circular de piedra en el sitio de Las Tinajeras (foto de Warren B. Church 2000).

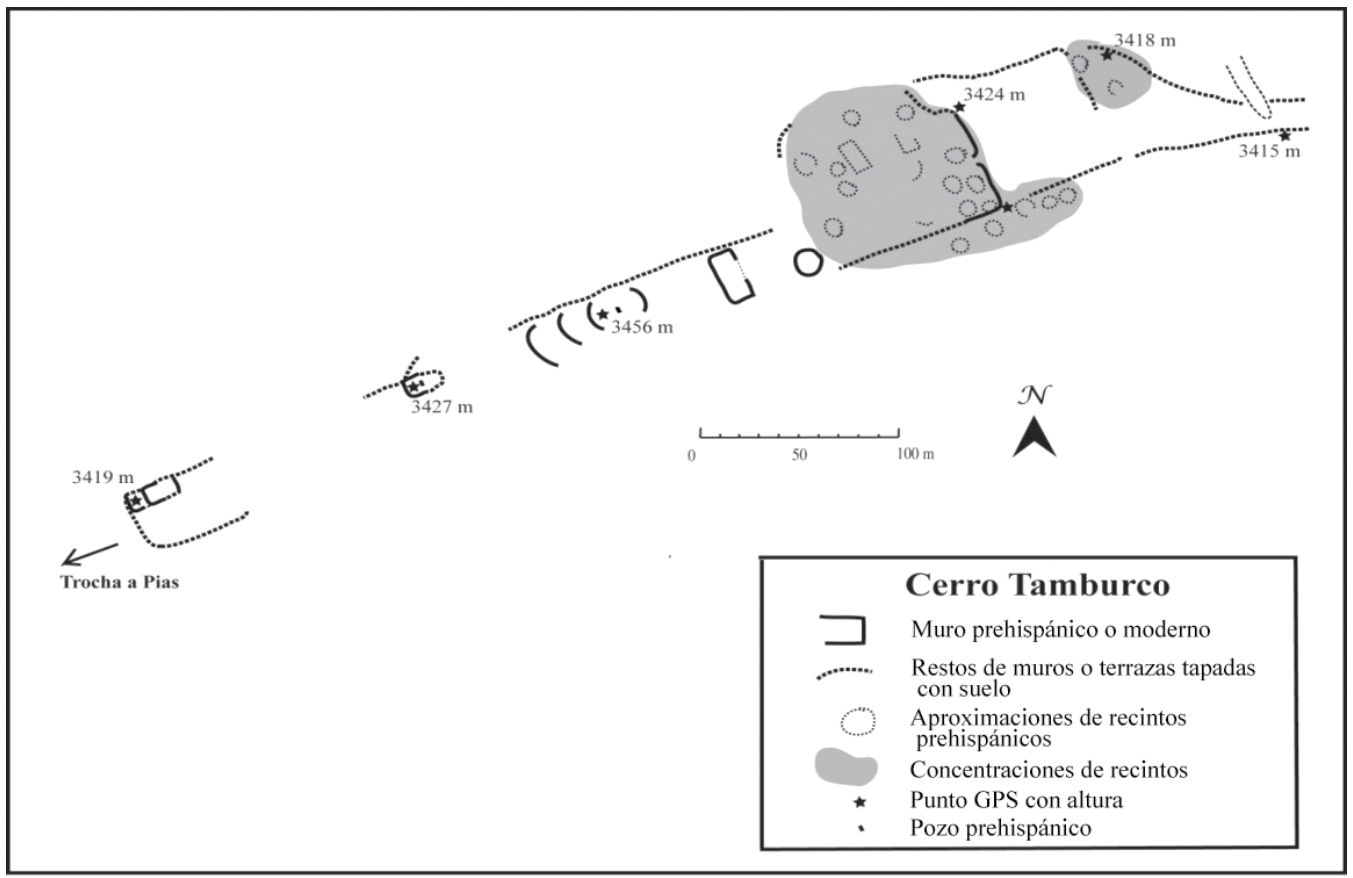

Figura 17. Croquis de restos del sitio de Cerro Tamburco (¿Pias Viejo?), ejecutado en el año 2000 con brújula y GPS de mano (W. Church y L. Valle). 


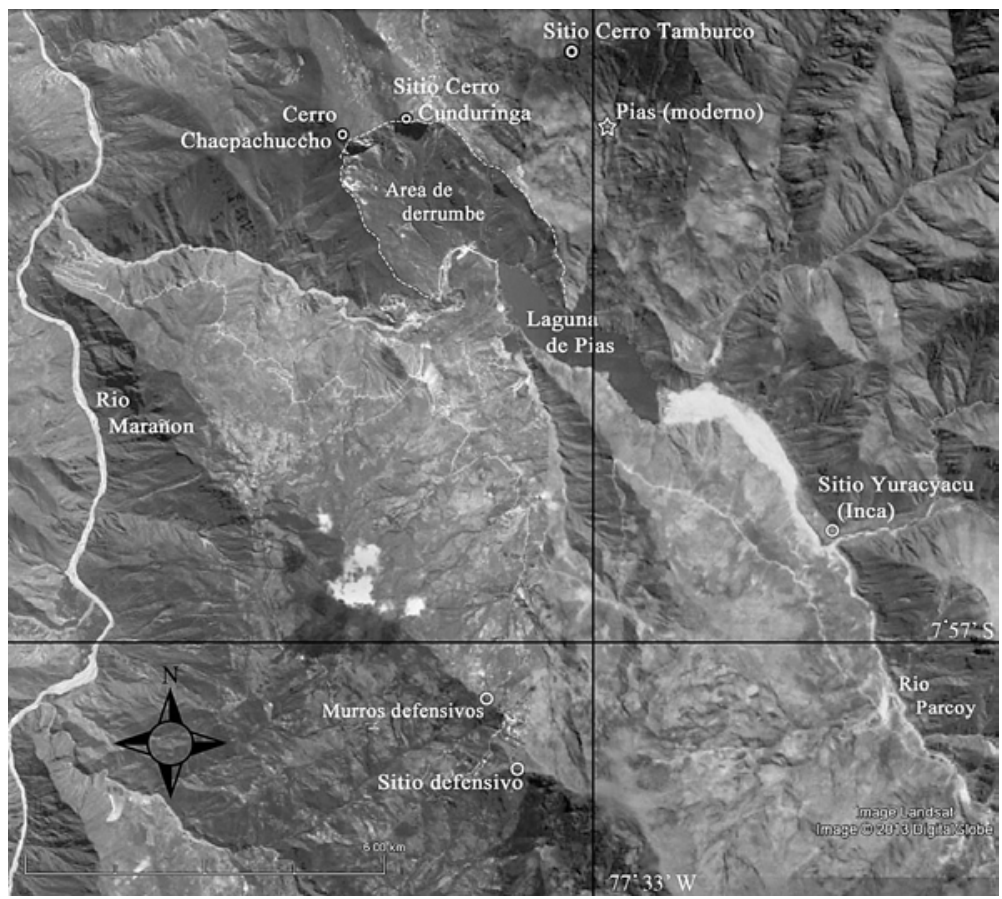

Figura 18. Imagen de satélite mostrando el área de derrumbe en el valle de Pias que tal vez corresponde a la leyenda citada en el texto (imagen de Google Earth).

Mediante la revisión de los datos, algunos de los cuales son nuevos, podemos rechazar la postulación de la reducción de los bosques sugerida por Thompson, y poner en duda el modelo de migración hacia el oriente propuesto por Moseley. El análisis de polen y de otros proxies paleoecológicos por el paleoecólogo Mark Bush (et al. 2005) en la laguna Chochos dentro de la cuenca del valle de Montecristo - que ahora se encuentra rodeada por un denso bosque-, no muestra evidencia de la deforestación, incrementos súbitos de trozos de carbón, ni de otros cambios repentinos de naturaleza antropogénica (Fig. 24). Existen evidencias de sequías regionales y tal vez asincrónicas en los Andes alrededor del año 1000 d.C. (Abbott et al. 1997; cf. Apaéstegui et al. 2014 (en el capítulo de introducción a este volumen)), pero las fechas de radiocarbono recuperadas de contextos de sitios Chachapoyas con arquitectura permanente se extienden desde el año 900 d.C. hasta 1500 d.C. (Guengerich 2014; Guengerich y Church este número). Así, los datos indican que las migraciones postuladas por Moseley habrían confrontado territorios ya ocupados y tal vez fortificados. Si los movimientos demográficos y las expansiones económicas propuestas por Moseley ocurrieron, entonces estas aparentemente no dejaron efectos tangibles en las poblaciones locales.

Cabe señalar que la escasez de evidencias arqueológicas de poblaciones densas y nucleadas en la sierra de Pataz, contrasta con la abundancia de sitios monumentales más arriba de varios pueblos de la sierra oriental como Uchucmarca al norte (Thompson 1973, 1976) y Chilia al sur (Curtin 1951). Trabajos científicos en otras regiones de Chachapoyas, como Luya (Ruiz Estrada 2011; Koschmieder 2012) y Chuquibamba (Schjellerup 1997), han descubierto restos arqueológicos y fechados radiocarbónicos que se remontan a épocas entre 100 a.C. y 500 d.C., pero hasta ahora no han publicado datos suficientes como para hacer una evaluación independiente de evidencia cerámica que podría apoyar o refutar las hipótesis de cambios abruptos que habrían causado una inmigración de escala, como la descrita por Koschmieder. Los procesos demográficos de toda esta región probablemente fueron variados e irregulares en el paso de tiempo, y no simultáneos a través de una geografía tan extensa y compleja. 


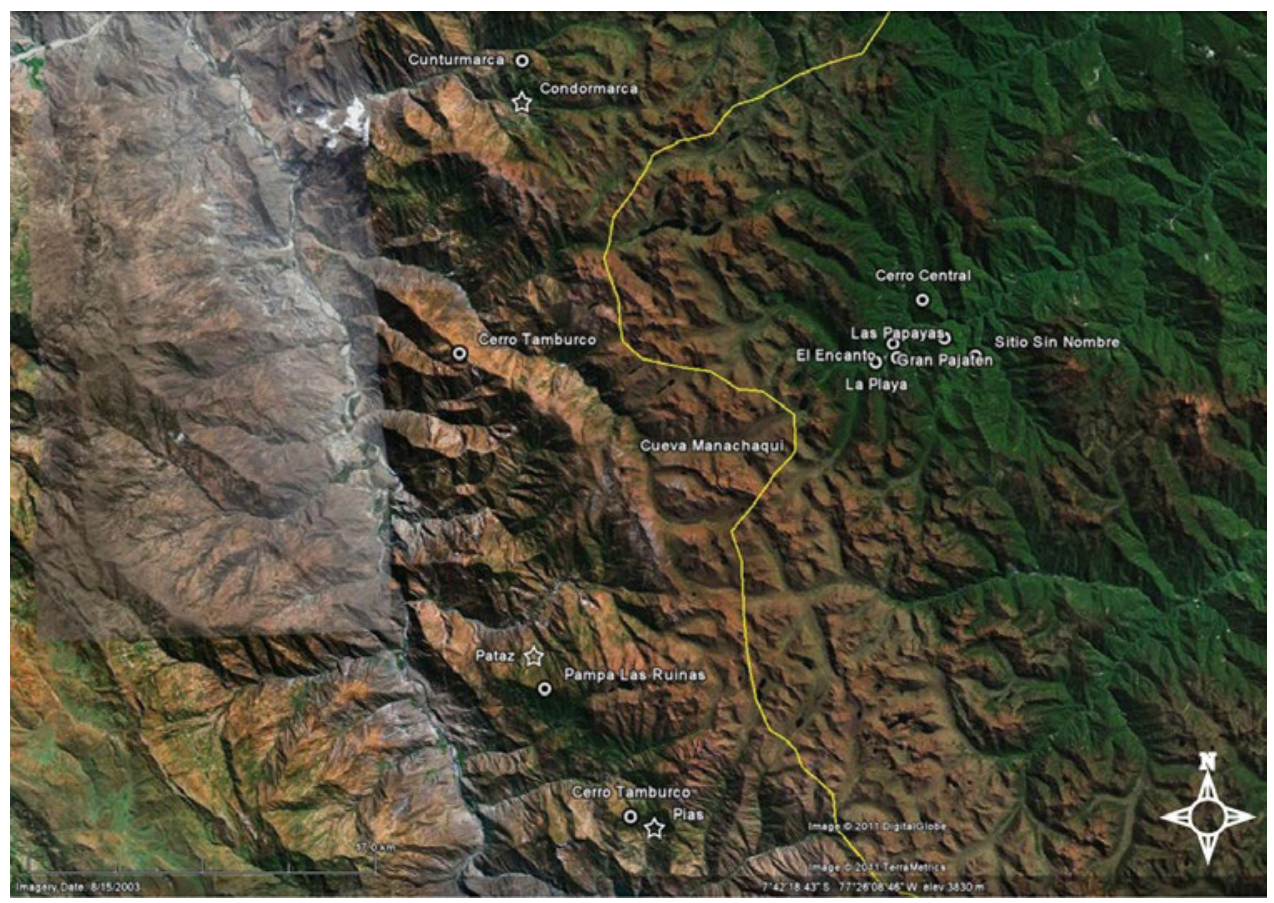

Figura 19. Imagen de satélite mostrando las ubicaciones de sitios arqueológicos del Grupo 2 (tempranos), algunas ciudades modernas y el limite del Parque Nacional del Río Abiseo (imagen de Google Earth).

\begin{tabular}{|lrr|}
\hline Proporciones: conteos de domicilios sierra a ceja de selva & \\
Cifras inferidas de las Visitas & $80: 1$ \\
& $\begin{array}{l}\text { Huánuco } \\
\text { Chuquito }\end{array}$ & $100-200: 1$ \\
Cifras estimadas del área de estudio & & \\
& Pataz-Montecristo & $<2: 1(3.5: 5)$ \\
\hline
\end{tabular}

Tabla 3. Proporciones: conteos de domicilios de la sierra de Pataz en relación con los del Valle Montecristo en la ceja de selva.

\section{Discusión e hipótesis alternativas}

Sobre la base de nuestra investigación, planteamos la hipótesis que la evidencia de ocupaciones tempranas recuperada en sitios abiertos y abrigos rocosos alrededor de Pataz, representan a grupos móviles o semimóviles, estacionales, que permanecían por períodos extendidos en ciertas localidades para la realización de actividades agrícolas y agropastoriles después de 300 d.C. La proximidad de zonas ecológicas diversas y accesibles a poca distancia una de la otra en las vertientes nororientales de la cordillera, habría presentado oportunidades económicas atractivas como el acceso directo y a poca distancia a una variedad de recursos. El registro de la cueva Manachaqui muestra evidencia de uso semipermanente y el cultivo de granos como la quinua dentro del valle a partir de 3000 a.C. (Pearsall 1996), coincidiendo con hallazgos palinológicos en sedimentos de la laguna Baja repor- 

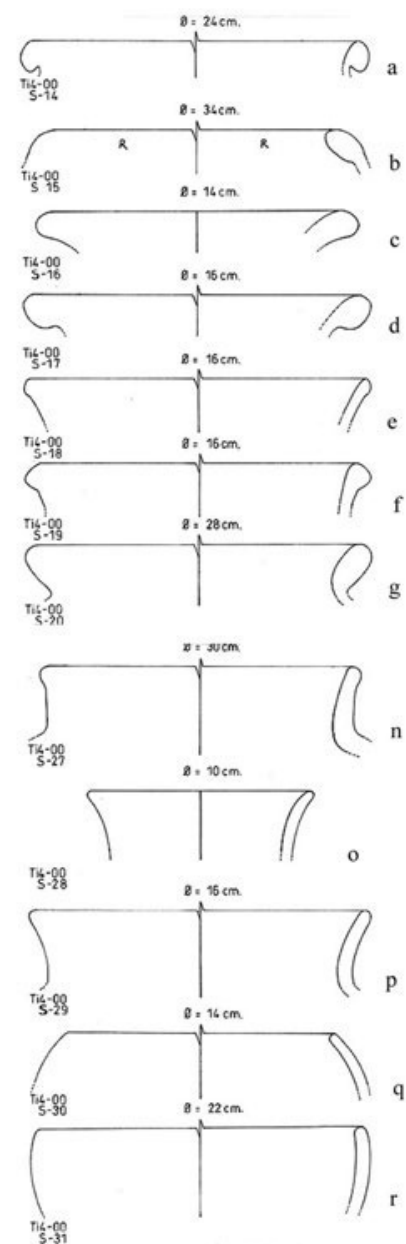
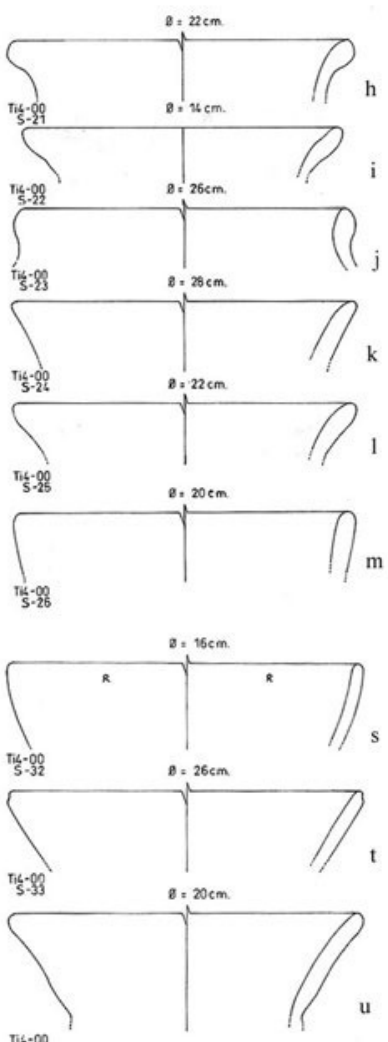

$\pi_{\xi=30}=34$

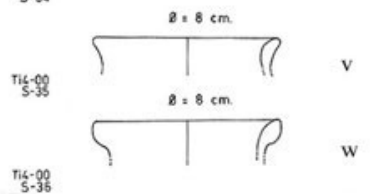

Figura 20. Perfiles de vasijas recogidas de la superficie del sitio de Cerro Tinajeras (dibujo de L.Valle).

tados por Hansen y Rodbell (1994). Luego, se observa evidencia botánica de cultivo del maíz a partir de 1500 a.C. en el norte (Bush et al. 2015), y maíz, frejoles y otras plantas alrededor de 900 a.C. en el sur dentro del área de estudio (Pearsall 1996). La introducción de los camélidos, evidenciada dentro de los estratos de Manachaqui entre 200 y 400 d.C. puede haber resultado en patrones trashumantes de subsistencia basados en elevaciones superiores. algunos cambios en inventario cerámico parecen indicar la extensión de redes de intercambio para incluir sociedades centroandinas. Aquí hay muchas hipótesis para explorar.

Los ańos menos conocidos corresponden al Horizonte Medio, aunque probablemente esté representado por restos culturales de producción local. La influencia indirecta del imperio Wari está representada dentro del paisaje Pataz-Abiseo en varios tiestos tricolor recuperados de la Cueva Chirimachay (Church 1994: 318, figs. 21, 22). Queda como pregunta importante determinar el por qué las poblaciones de la región de Chachapoyas comenzaron a construir núcleos de piedra alrededor de 900 d.C., sacrificando movilidad y el acceso directo a los recursos de los que gozaron anteriormente. La nueva practica de invertir tiempo y trabajo para edificar asentamientos con viviendas y otras estructuras de piedra, puede indicar una mayor preocupación por la defensa, asociada a un incremento del conflicto en la región. Sin embargo, si esta práctica de construir con 

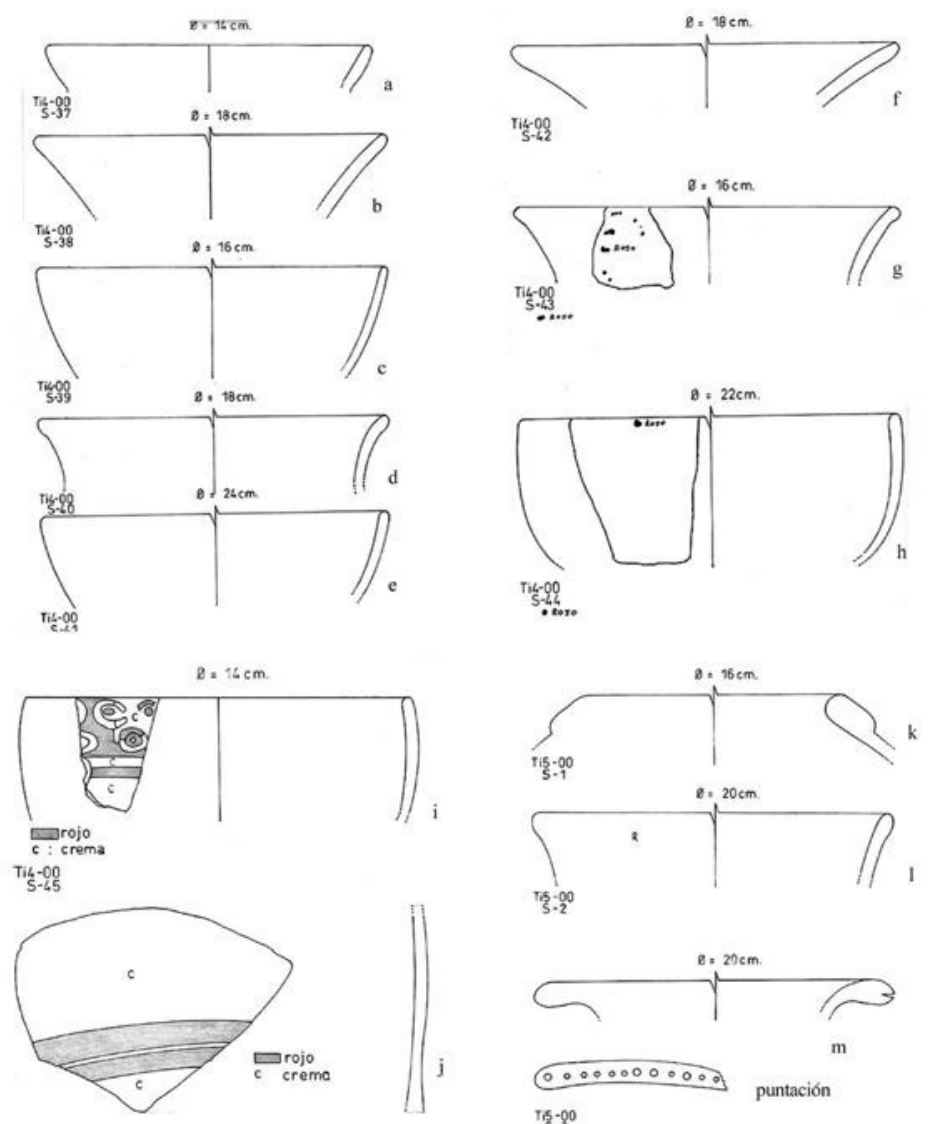

Tร్.

$\underset{S}{T \rightarrow 460}-00$

Figura 21. Perfiles de vasijas recogidas de la superficie del sitio de Cerro Tinajeras (dibujo de L.Valle).

piedra resultó de cambios políticos, entonces es muy probable que las investigaciones y análisis futuros de secuencias de desarrollo y de fechas radiocarbónicas vayan a revelar cambios que no fueron homogéneos ni simultáneos. Probablemente fueron respuestas locales que ocurrieron de modo asincrónicos, a pasos distintos en cada área, y según circunstancias geopolíticas distintas que se presentaron. Las sociedades ubicadas en lados flancos del río Utcubamba y las sociedades en las zonas norte y sur de la gran área de Chachapoyas probablemente estuvieron motivadas a adoptar nuevas prácticas en tiempos distintos, respondiendo a diversas circunstancias locales.

Nos causa extrañeza que algunos arqueólogos intenten descalificar nuestra hipótesis de desarrollo autóctono y autónomo en paisaje Pataz-Abiseo por medio de representaciones falsas de nuestros datos y los resultados divulgados de las investigaciones arqueológicas entre 1985 y 1990 (v.g. Church 1991, 1994, 1996, 1997; Church y von Hagen 2008). Koschmieder (2012: 13, 2014: 243) se equivoca cuando declara que «queda un obvio vacío de más de 1000 años en los registros cronológicos que no explican los sustentadores de esta hipótesis». Aquí presentamos un cuadro con todas las fechas radiocarbónicas recogidas ya reportados dentro de publicaciones citadas (Fig. 25), menos las fechas del Precerámico Temprano de Manachaqui y del Horizonte Tardío de Gran Pajatén. Se puede observar que no existe tal vacío largo, ni consideran que todavía no hemos investigado lo suficiente como para explicar las fechas en términos de eventos históricos.

Para Koschmieder y Kauffmann, toda la evidencia de ocupación humana anterior a 800 o 900 a.C. corresponde a una época cultural que llaman «pre-Chachapoyas». Para Kauffmann, la misma época 

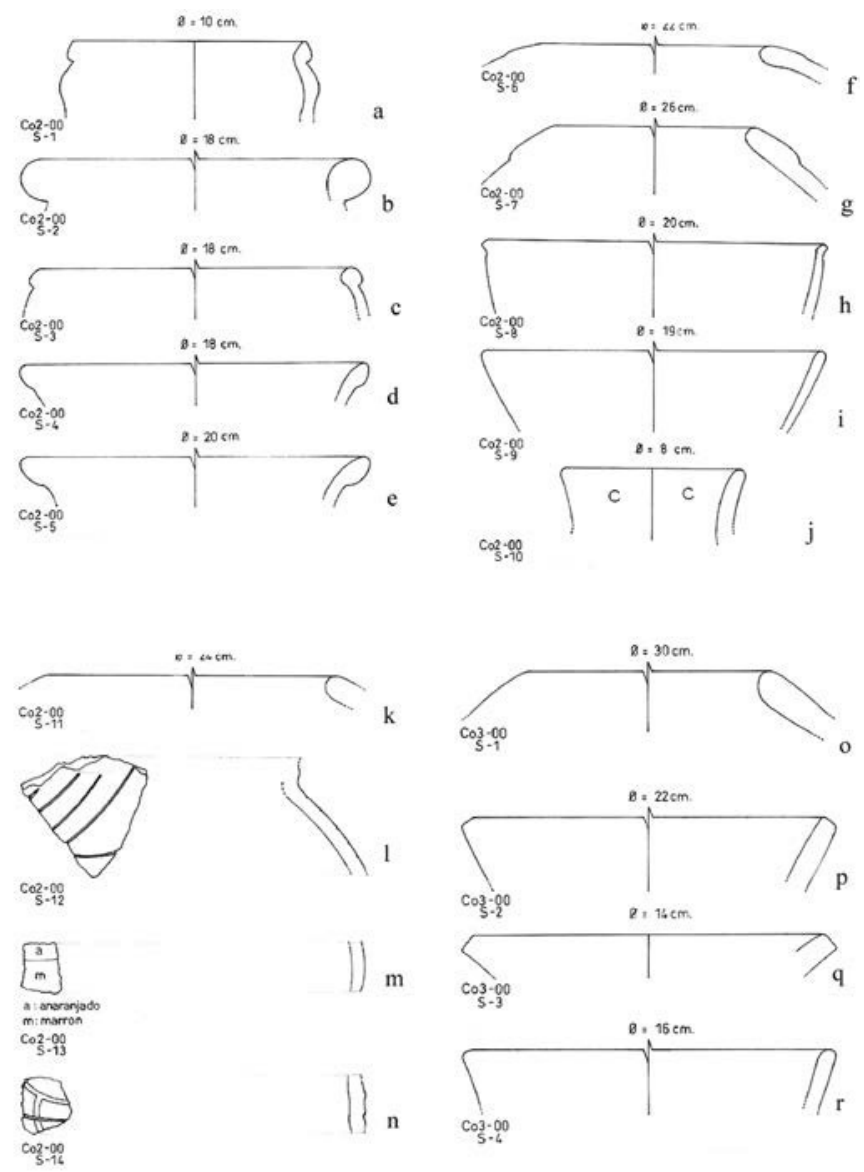

Figura 22. Perfiles de vasijas recogidas de la superficie del sitio de La Colpa (dibujo de L. Valle).

se puede clasificar como "pre-agrícola». Refiriéndose a la cueva Manachaqui, Kauffmann sostiene que, «los testimonios hallados son fundamentalmente utensilios de piedra correspondientes a sociedades preagrícolas y, por lo mismo, distantes en lo cronológico y lo cultural de quienes levantaron Pajatén, Cerro Central y Los Pinchudos» (Kauffmann 2009: 97). Esta crítica nos hace concluir que Kauffmann no conoce los resultados de las investigaciones en la cueva de Manachaqui, aunque estos han sido divulgados en varias oportunidades (Church 1996, 2004; Church y von Hagen 2008). Valga repetir que Manachaqui rindió restos de maíz, frejoles y otras plantas fechados c. 900 a.C., y se puede hipotizar el cultivo de Chenopodium dentro del valle Manachaqui c. 2250 a.C.

Otra crítica particular que comparten Kauffmann y Ligabue, y Koschmieder es que, «no existen testimonios que señalan un gradual desarrollo a partir de aquellas lejanas edades» (Kauffmann y Ligabue 2003: 38), y «no existen testimonios que señalan un gradual desarrollo a partir de tiempos bien tempranos» (Koschmieder 2012: 13). En respuesta, planteamos la pregunta, ¿Dónde en los Andes se encuentra una secuencia que demuestre «un desarrollo gradual»? Rowe y Menzel (Rowe 1962) aprovecharon disyunciones cronológicas resultantes de alternaciones entre períodos de desarrollo rápido, lento y puntuado a través del tiempo y el espacio observadas en el registrado del valle de Ica para proponer su periodización centroandina constituida de períodos y horizontes. Moseley (1987) y Bawden y Reycraft (2009) caracterizan el desarrollo cultural en los Andes como «equilibrio interrumpido». La idea del desarrollo cultural gradual es una suposición inserta en el marco teórico defectuoso del siglo XIX de evolución cultural unilineal. En realidad, nuestra secuencia 

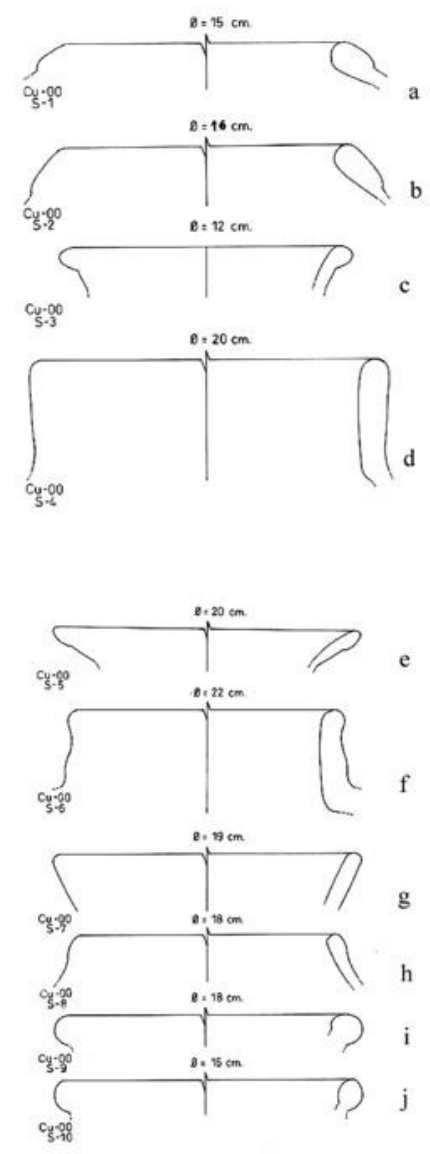

Figura 23. Perfiles de vasijas recogidas de la superficie del sitio de Cerro Cunduringa. (dibujo de L.Valle).

se asemeja en muchos aspectos a las secuencias de otras regiones sudamericanas. La secuencia de estilos alfareros que recogimos de la cueva de Manachaqui exhibe atributos tecnológicos, morfológicos y decorativos que cambian muy poco a través del tiempo (Church y von Hagen 2008).

Por último, cualquier cambio brusco identificado en la secuencia de nuestra área de estudio y en otras secuencias de la ceja de selva es esperable debido a la ubicación fronteriza de los sitios (Lightfoot y Martínez 1995). La interpretación de la arqueología de Chachapoyas puede beneficiarse de marcos teóricos contemporáneos alternativos basados en procesos culturales conocidos de situaciones fronterizas, en estrategias de movilidad, en los ciclos de fisión-fusión y en la etnogénesis. Las migraciones a pequeña escala, la interacción y el matrimonio con las poblaciones vecinas, probablemente jugaron un papel importante en el aumento de población hacia el fin del Horizonte Medio en todo el norte peruano. Nosotros reconocemos la importancia de movimientos poblacionales en los Andes y también el potencial impacto de cambios climáticos como propulsores de cambios demográficos. Sin embargo, la evaluación de la utilidad de estos marcos requiere datos espaciales y temporales detallados, de los cuales carecemos. Hasta ahora no se han publicado fechas de radiocarbono en asociación directa con la arquitectura de Chachapoyas que antecedan a $850 \mathrm{~d}$.C. (Guengerich 2015), aunque se han llevado a cabo muy pocas excavaciones controladas en la región.

Aseveramos que el desarrollo cultural en esta parte de la ceja de selva debe considerarse primordial y singular, asemejando en este sentido los desarrollos en otras regiones andinas. Es probable que esta región siempre sea considerada como «el área cultural Chachapoyas» o el área de la "Cultura Chachapoyas», como ha sido costumbre, pero urgimos que se tome en cuenta la signi- 


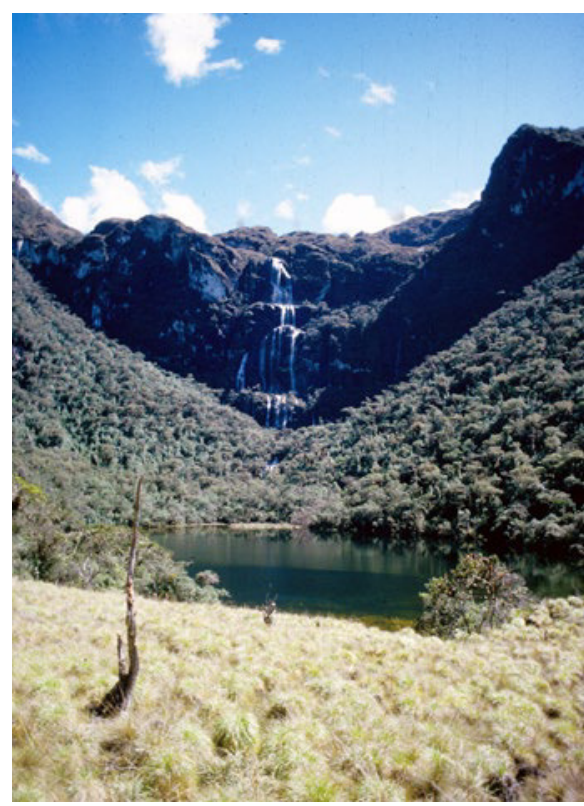

Figura 24. Vista de la laguna Los Chochos (foto de W. B. Church 1986).

ficancia de tales términos y etiquetas, y de sus orígenes como descritos en el capítulo introductorio. Tales términos conducen a la tendencia errada de investigar la región como una totalidad cultural unificada, que no fue el caso. Ya existen indicios que futuras investigaciones arqueológicas dentro del sur de Chachapoyas van a revelar trayectorias culturales distintas a aquellas en el norte.

Concluimos que los datos arqueológicos no son compatibles con las propuestas de orígenes migratorios de la cultura Chachapoyas. Ninguno de los proponentes de estas teorías siquiera puede identificar de manera convincente la fuente específica donde se derivaron las poblaciones. Por lo tanto, este tipo de movimiento poblacional es imposible de rastrear. La arquitectura, los estilos de cerámica, la iconografía y todas las clases de restos materiales de la región de Chachapoyas reflejan orígenes primordiales en la ceja de selva nororiental. Los períodos de intensa interacción interregional en este cruce de caminos, seguramente enriquecieron al desarrollo cultural. Los resultados de recientes análisis de $\mathrm{ADN}$ de la población contemporánea, han determinado la presencia marcadores genéticos con una antigüedad de aproximadamente 7000 ańos dentro de la región (Barbieri et al. 2017; Guevara este número). Estos nuevos datos comprueban que se debe concebir a las sociedades de Chachapoyas como autóctonas y que ya es momento de cerrar el debate anacrónico sobre los orígenes del núcleo poblacional. Actualmente se esperan los resultados de análisis de restos humanos prehispánicos de la región para conocer más al fondo su historia demográfica. La movilidad intrarregional tanto como los movimientos interregionales de familias y comunidades (y no de culturas enteras) deben haber jugado un papel importante en la prehistoria de Chachapoyas, pero los arqueólogos ya tienen que abandonar el uso de modelos anticuados e incapaces de captar la complejidad de la demografía prehispánica de Chachapoyas.

\section{Agradecimientos}

Nuestra investigación se hizo posible gracias al financiamiento generoso de la Fundación para Exploración e Investigación sobre las Orígenes de las Culturas (FERCO), la Resolución Directoral Nacional No. 848 emitida por el Instituto Nacional de Cultura, y la autorización No. 23-S/C-2000INRENA-DGANPFS-DANP emitida por el Instituto Nacional de Recursos Naturales. Agradecemos el Comité Científico de FERCO, especialmente su comité ejecutivo, los doctores Daniel Sandweiss, James Richardson y el fundador de FERCO, el fallecido explorador Thor 


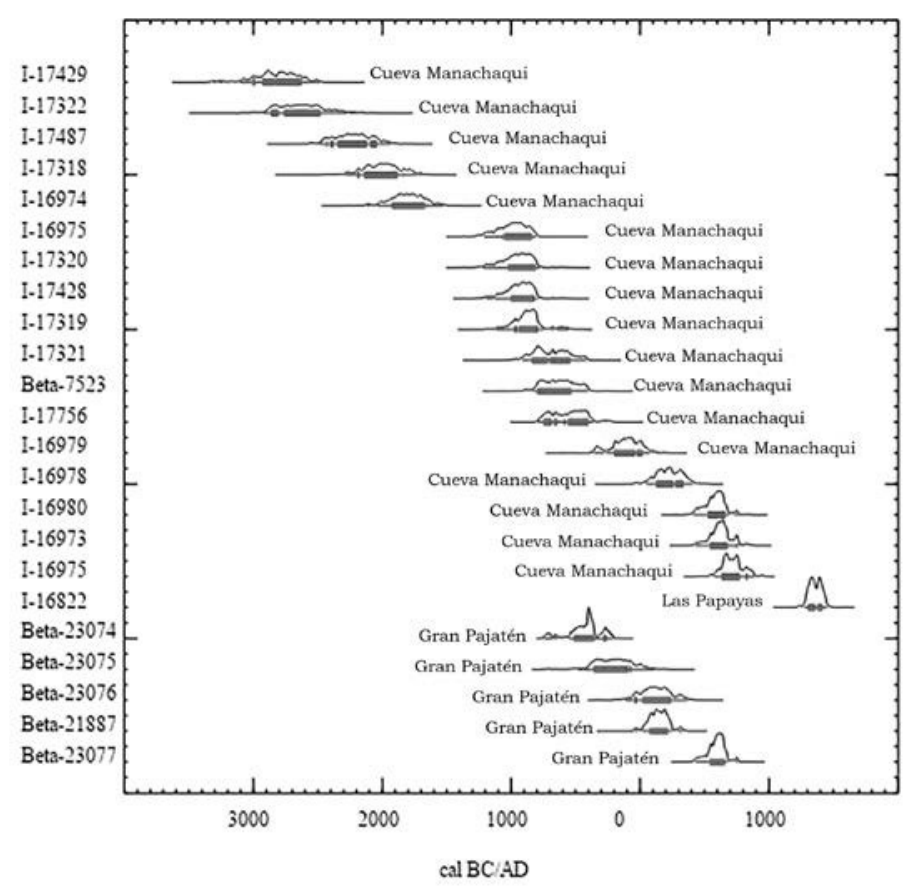

Figura 25. Cuadro con fechas radiocarbónicas de los tres sitios de cueva Manachaqui, La Playa y Gran Pajatén, demostrando una secuencia de presencia humana a partir de 3000 a.C. en el paisaje Pataz-Abiseo. Fechas tardias del Horizonte Tardio de Gran Pajatén omitidas (W. Church con curva de calibración IntCal 13 (Reimer et al. 2013).

Hyerdahl. Este proyecto fue concebido por Church durante su residencia en Dumbarton Oaks. Por consiguiente, agradecemos al entonces director del Programa Pre-Columbino Jeffrey Quilter. El codirector Valle se encargó del análisis de las colecciones recogidas. También agradecemos por su apoyo administrativo a los Directores de Arqueología Ana María Hoyle y César Gálvez Mora del INC-Trujillo, y el licenciado Jorge Cotrina, supervisor de proyecto en el campo. Para nosotros son héroes nuestros guías, obreros y amigos Macedonio Gonzales Cueva, Elías Zegarra, Jorge Alguilar Acosta, Calixto Ramirez, Cisto Torres. Nos ofrecieron su apoyo generosamente los Señores Alcaldes Andrés Salvatierra de Pias y Alejandro Jolner Arranda Campos de Pataz; el ingeniero Carlos Riveros, director del Instituto Tecnológico Superior de Pataz; el profesor Esteban Alayo Briseño, jefe administrador del Parque Nacional Río Abiseo; y los vecinos de Patas, Pías y Condormarca quienes nos dieron la bienvenida. Por su apoyo logístico y moral agradecemos a la bióloga Mariella Leo Luna y la buena gente de APECO. Debemos un agradecimiento profundo a los individuos e instituciones aquí mencionados y a otros no indicados, por el apoyo dado para realizar nuestra investigación.

\section{REFERENCIAS}

Abbott, M.B., M.W. Binford, M. Brennery y K.R. Kelts

1997 A 350014 C yr high-resolution record of water-level changes in Lake Titicaca, Bolivia/Peru, Quaternary research 47(2), 169-180.

Adams, W. Y., D.P. Van Gerven y R. S. Levy

1978 The retreat from migrationism, Annual Review of Anthropology 7, 483-532.

Barbieri, C., Sandoval, J.R., Valqui, J., Shimelman, A., Ziemendorff, S., Schröder, R., Geppert, M., Roewer, L., Gray, R., Stoneking, M. and Fujita, R.

2017 Enclaves of genetic diversity resisted Inca impacts on population history, Scientific Reports 7(1), 17411. 
Basadre, M.

1892 Torre de Babel en el Perú, Boletín de la Sociedad Geográfica de Lima 1:10, 11, 12: 440-445.

Bawden, G y R. Reycraft

2009 Exploration of punctuated equilibrium and culture change in the archaeology of Andean ethnogenesis, Andean Civilization: A Tribute to Michael E. Moseley, 195-210. Cotsen Institute of Archaeology, University of California, Los Angeles.

Bonavia, D.

1968 Las ruinas del Abiseo, Universidad Peruana de Ciencias y Tecnología, Lima.

2000 The role of the ceja de selva in the cultural development of pre-Columbian Peru, en: L. Minelli (ed.), The Inca World: The Development of Pre-Columbian Peru, AD1000-1534, 121-131, University of Oklahoma Press, Norman.

\section{Bonavia, D. y R. Ravines}

1967 Las fronteras ecológicas de la civilización andina, Amaru 2, 61-69.

1968 Villas del Horizonte Tardio en la Ceja de Selva del Perú: Algunas Consideraciones, Actas y Memorias del XXXVII Congreso Internacional de Americanistas, vol. 1, 153- 160, Mar de Plata.

Bradley, R.

2005 The architecture of Kuelap, tesis de doctorado, Departamento de Historia de Arte, Columbia University, New York.

Briceño, J.

2000 Patrimonio cultural en el distrito de Pías, Provincia de Pataz, Informe sin publicar en archivo de la Municipalidad de Pias.

Bueno Mendoza, A. y M. Cornejo García

2009 Arqueología de la cuenca del Río Guabayacu, región San Martín, Perú, Investigaciones Sociales 13(23), 15-58.

Bush, M.B., Hansen, B., Rodbell, D.T., Seltzer, G.O., Young, K.R., León, B., Abbott, M.B., Silman, M.R. y Gosling, W.D.

2005 A 17,000-year history of Andean climate and vegetation change from Laguna de Chochos, Peru, Journal of Quaternary Science 20, 703-714.

Cabana, G.S. y J.J. Clark

2011 Rethinking anthropological perspectives on migration, University Press of Florida.

Cameron, C.M.

2013 How people moved among ancient societies: broadening the view. American Anthropologist 115(2), 218231.

Cedrón Goicochea, E.

1989 Cronología e identificación de función en tres edificios prehispánicos del sitio La Playa, Departamento de San Martín, Perú, tesis de licenciatura, Departamento de Arqueología, Universidad Nacional de Truijllo, Trujillo.

Chamberlain, A.

2006 Demography in Archaeology, Cambridge University Press, Cambridge.

Church, W.

1991 La ocupación temprana de Gran Pajatén, Revista del Museo de Arqueología Antropología e Historia de la Universidad Nacional de Trujillo 2, 7-38.

1994 Early occupations at Gran Pajatén, Peru, Andean Past, 4, 281-318.

1996 Prehistoric Cultural Development and Interregional Interaction in the Tropical Montane Forests of Peru, tesis de doctorado, Department of Anthropology, Yale University.

1997 Más allá del Gran Pajatén: conservando el paisaje prehispánico Pataz-Abiseo, Revista del Museo de Arqueología, Antropología, e Historia 7, 205-248.

2004 Buscando las raíces de los Chachapoyas, Sian 9, 15, 4-5.

Church, W. y A. von Hagen

2008 Chachapoyas: cultural development at an Andean cloud forest crossroads, en: H. Silverman y W. Isbell (eds.), Handbook of South American Archaeology, 903-926. Springer, Nueva York. 
Diez de San Miguel, G. D., P. G. Flores y J. V. Murra

1964 Visita hecha a la provincia de Chucuito por Garci Diez de San Miguel en el año 1567, Casa de la Cultura del Perú. Lima.

Curtin, P.D. y G.R. Willey

1951 A survey of new archaeological sites in Central Pataz, Peru, Journal of the Washington Academy of Sciences $41(2), 49-63$.

Dillehay, T. D.

1979 Pre-Hispanic resource sharing in the central Andes, Science 204(4388), 24-31.

2013 Economic mobility, exchange, and order in the Andes, en: K.G. Hirth y J. Pillsbury (eds.), Merchants, markets, and exchange in the pre-Columbian world, 283-308, Dumbarton Oaks Pre-Columbian Research Symposia y Colloquia, Washington, D.C.

Earle, T., T. D’Altroy, C. Hastorf, C. Scott, C. Costin, G. Russell y E. Sandefur

1987 Archaeological Field Research in the Upper Mantaro, Peru, 1982-1983: Investigations of Inka Expansion and Exchange, Institute of Archaeology, Monograph 28, University of California, Los Angeles, Los Angeles.

Espinoza Soriano, W.

1967 Los señoríos étnicos de Chachapoyas y la alianza hispano-chacha, Revista Histórica 30, 224-332.

Gaither, C., K. Koschmieder y G. P. Lombardi

2008 En la tierra de los gigantes: Un nuevo 'gigante' encontrado en el sitio nor-Andino de Chichita, Perú, Archaeobios 2, 28.

Garcilaso de la Vega, I.

1966 Royal Commentaries of the Incas and General History of Peru, Part I. [traducido por H. V. Livermore],

[1609] University of Texas Press, Austin.

Guengerich, A.

2014 The architect's signature: The social production of a residential landscape at Monte Viudo, Chachapoyas, Peru, Journal of Anthropological Archaeology 34, 1-16.

2015 Settlement organization and architecture in Late Intermediate Period Chachapoyas, Northeastern Perú, Latin American Antiquity 26(3), 362-381.

Guevara, E. K., J. U. Palo, S. Guillén y A. Sajantila

2016 MtDNA and Y-chromosomal diversity in the Chachapoya, a population from the northeast Peruvian Andes-Amazon Divide, American Journal of Human Biology 28(6), 857-867.

Guillén, S.

2002 The mummies of the Laguna de los Cóndores, en: E. González y R. León (eds.), Chachapoyas: el reino perdido, 345-387, AFP Integra, Lima.

von Hagen, A.

2002 Chachapoya iconography and society at Laguna de los Cóndores, Peru, en: H. Silverman y W. Isbell (eds.), Andean Archaeology, Volume II: Art, Landscape, and Society, 137-155, Kluwer Academic/Plenum, Nueva York.

Isbell, W.

1968 New discoveries in the montaña of southern Peru, Archaeology 21(2), 108-114.

1974 Ecología de la Expansión de los Quechua-hablantes, Revista del Museo Nacional 40, 139-155.

\section{Kauffmann Doig, F.}

1983 Manual de Arqueología Peruana, 8va edición, Peisa, Lima.

1987 Andes amazónicos: investigaciones arqueológicas 1980-1986 (Expediciones Antisuyo), Banco Continental, Lima.

1991 Sobrepoblación en los Andes / una explicación del origen y proceso de la cultura andina, Limaginaire (Alianza Francesa) 3, 45-48, Lima.

2009 Constructores de Kuélap y Pajatén, los Chachapoyas, Derrama Magisterial, Lima.

2013 (ed.) Los Chachapoyas, Banco de Crédito de Perú, Lima.

Kauffmann Doig, F. y G. Ligabue

2003 Los Chachapoya(s): moradores ancestrales de los Andes amazónicos peruanos, Universidad Alas Peruanas, Lima. 
Kauffmann Doig, F, M. Salazar, D. Morales, I. Mackay y O. Sacay

1989 Andes amazónicos: sitios intervenidos por la expedición Antisuyo/86, Arqueológicas 20, Museo Nacional de Arqueología y Antropología. Lima.

Koschmieder, K.

2012 Jucusbamba: Investigaciones arqueológicas y motivos Chachapoya en el norte de la provincia de Luya, departamento Amazonas, Perú, Tarea Asociación Grafica Educativa, Lima.

2014 Los orígenes y el desarrollo de la organización sociopolítica de la cultura Chachapoya: una mirada desde la provincia de Luya, departamento de Amazonas, Perú, en: S. Rostain (ed.), Antes de Orellana (Actas del 3er Encuentro Internacional de Arqueología Amazónica), 243-249, 528-529, Instituto Francés de Estudios Andinos, Quito.

Knudson, K. J.

2011 Identifying archaeological human migration using biogeochemistry: case studies from the South Central Andes, en: G.S. Cabana y J.J. Clark (eds.), Rethinking anthropological perspectives on migration, 231-247, University Press of Florida, Tallahassee.

Knudson, K. y D. E. Blom

2009 The complex relationship between Tiwanaku mortuary identity and geographic origin in the South Central Andes, en: K. J. Knudson y C. M. Stojanowski (eds.), Biology and identity in the Americas, 194211, University Press of Florida, Gainesville.

Lathrap, D.

1970 The Upper Amazon, Thames and Hudson, London.

Lennon, T. J.

1992 Una reseña del programa de estudios sobre los recursos culturales del Parque Nacional Río Abiseo: 1985-1990, ponencia presentada en el simposio: Biodiversidad, Historia Cultural y Futuro del Parque Nacional Río Abiseo, 17 al 20 de agosto, Lima.

Lennon, T., W. Church y M. Cornejo

1989 Investigaciones arqueológicas en el parque nacional Río Abiseo, Boletín de Lima 62, 43-56.

Lennon, T., M. Cornejo y W. Church

1987 Informe final: Investigaciones sobre los recursos culturales en el Parque Nacional del Río Abiseo, informe presentado al Instituto Nacional de Cultura, Lima.

Lightfoot, K. G. y A. Martínez

1995 Frontiers and boundaries in archaeological perspective, Annual Review of Anthropology 24, 471-492.

Miranda, C. de

1906 Relación de los corregimientos y otros oficios que se proveen en los Reynos é provincias del Piru, en el distrito é gobernación del Visorrey dellos (1583), en: V. Maúrtua (ed.), Juicio de límites entre el Perú y Bolivia, prueba peruana presentada al gobierno de la República Argentina, vol. 1, 168-280, Henrich y comp., Barcelona.

Morales Chocano, D.

1993 Compendio histórico del Perú, Tomo I: historia arqueológica del Perú, Editorial Milla Batres, Lima.

Morales Gamarra, R., L. Valle Álvarez, W. Church y L. Coronado Tello

2002 Los Pinchudos: mausoleo polícromo de los Andes nor-orientales del Perú, Sian 8(12), 3-41.

Moseley, M.

1992 The Incas and Their Ancestors, Thames and Hudson, London.

1997 Climate, culture, and punctuated change: New data, new challenges, The Review of Archaeology 18(1), $19-28$.

2001 The Incas and Their Ancestors, 2da edición, Thames and Hudson, London.

2002 Modeling protracted drought, collateral natural disaster, and human responses in the Andes, en: S. M. Hoffman y A. O. Smith (eds.), Catastrophe and Culture: The Anthropology of Disaster, 187-212, School of American Research Press, Santa Fe.

Murra, J.

1972 El «control vertical» de un máximo de pisos ecológicos en la economía de las sociedades andinas, en: Vista de la Provincia de León de Huánuco (1562), Ińigo Ortiz de Zúñiga, II. J. V. Murra, Ed. Universidad Hermilio Valdizán, 429-476, Huánuco. 
Narváez Vargas, A.

2013 Kuelap: centro del poder politico religioso de los Chachapoyas, en: F. Kauffmann (ed.), Los Chachapoyas, 87-159, Colección Arte y Tesoros del Perú, BCP, Lima.

Nystrom, K.

2006 Late Chachapoya population structure prior to Inka conquest, American Journal of Physical Anthropology $131,334-342$.

2009 The reconstruction of identity: A case study from Chachapoya, Peru, en: K. J. Knudson y C. M. Stojanowski (eds.), Bioarchaeology and Identity in the Americas, 82-102. University of Florida Press, Gainesville.

Olivera Núñez, Q.

2014 Arqueología alto amazónica. Los orígenes de la civilización en el Perú, Apus Graph Ediciones, Lima.

Paz Esquerre, E.

1990 Tradicion oral del departamento de La Libertad, CONCYTEC, Lima.

Pimentel, V.

1967 Pajatén, Fénix (Revista de la Biblioteca Nacional) 17, 34-38.

Ravines, R. y R. Matos

1983 Inventario de monumentos arqueológicos del Perú, Zona Norte, Instituto Nacional de Cultura, Lima.

Reimer, P. J., Bard, E., Bayliss, A., Beck, J. W., Blackwell, P. G., Bronk Ramsey, C., Grootes, P. M., Guilderson, T. P., Haflidason, H., Hajdas, I., HattŽ, C., Heaton, T. J., Hoffmann, D. L., Hogg, A. G., Hughen, K. A., Kaiser, K. F., Kromer, B., Manning, S. W., Niu, M., Reimer, R. W., Richards, D. A., Scott, E. M., Southon, J. R., Staff, R. A., Turney, C. S. M., \& van der Plicht

2013 IntCal13 and Marine13 Radiocarbon Age Calibration Curves 0-50,000 Years cal BP. Radiocarbon, 55(4).

Rivera Serna, R.

1955 Libro primero de cabildos de San Juan de la Frontera de Chachapoyas, Fénix (Revista de la Biblioteca

Rivet, P. Nacional) 11, 318 .

1968 Les elements constitutifs des civilisations du nordouest et de l'ouest Sud-americain, International Congress of Americanists, 1-20, Gothenburg 1924, Kraus Reprint, Nendeln/Liechtenstein.

Roberts, B. K.

1996 Landscapes of settlement: Prehistory to the present, Routledge Press, New York.

Rojas Ponce, P.

1966 Un Informe sobre las Ruinas del Pajatén, Cuadernos Americanos 148 (5), 119-127.

Rouse, I.

1958 The Inference of Migrations from Anthropological Evidence, en: R. H. Thompson (ed.), Migrations in new world culture history, 63-68, University of Arizona Press, Tucson.

1986 Migrations in prehistory: Inferring population movement from cultural remains, Yale University Press, New Haven.

Rowe, J. H

1962 Stages and periods in archaeological interpretation, Southwestern Journal of Anthropology 18(1), 40-54.

Ruiz Estrada, A.

2009 Alfarería de Kuélap: tradición y cambio (1972), Avqi Ediciones, Lima.

2011 Amazonas: arqueología e historia, Universidad Alas Peruanas, Lima.

Schjellerup, I.

1997 Incas and Spaniards in the conquest of the Chachapoyas: Archaeological and ethnohistorical research in the north-eastern Andes of Peru, National Museum of Denmark, Department of Ethnography, Copenhagen.

Shady Solis, R.

1987 Tradición y cambio en las sociedades formativas de Bagua, Amazonas, Perú, Revista Andina 5 (2), 457 488. 
Steward, J.

1948 Tribes of the montaña: an introduction, en: J. Steward (ed.), Handbook of South American Indians, vol. 3: The tropical forest tribes, 507-533, Bureau of American Ethnology Bulletin 143, Smithsonian Institution, Washington, D.C.

1972 Theory of culture change: The methodology of multilinear evolution, University of

[1955] Illinois Press, Urbana.

Sutter, R. C. y J. W. Verano

2006 Biodistance analysis of the Moche sacrificial victims from Huaca de la Luna Plaza 3C: Matrix method test of their origins, American Journal of Physical Anthropology, 132(2), 193-206.

Tello, J. C.

1921 Introducción a la Historia Antigua del Perú, Editorial Euforion, Lima.

1942 Origen y Desarrollo de las Civilizaciones Prehist6ricas Andinas, Actas y Trabajos Cientificos del XVII Congreso Internacional de Americanistas, Lima 1939, tomo I, 589-720, Lima.

1943 Discovery of the Chavín culture in Peru, American Antiquity 9(1), 135-160.

Thompson, D.

1973 Archaeological investigations in the Eastern Andes of Northern Peru, Acts of the 39th International Congress of Americanists, vol. 1, 363-369, Rome/Genoa.

1976 Prehistory of the Uchucmarca Valley in the North Highlands of Peru, Proceedings of the of the 41st international Congress of Americanists, 99-106.

Thompson, L.G., E. Mosley-Thompson, J. F. Bolzan y B. R. Koci

1985 A 1500-year record of tropical precipitation in ice cores from the Quelccaya ice cap, Peru, Science, 229(4717), 971-973.

1994 Glacial records of global climate: A 1500-year tropical ice core record of climate, Human Ecology 22(1), 83-95.

Toyne, J. M., W. B. Church, J. L. Coronado Tello, R. Morales Gamarra

2017 Exploring imperial expansion using an isotopic analysis of paleodietary and paleomobility indicators in Chachapoyas, Peru, American Journal of Physical Anthropology 162(1), 51-72.

Trigger, B.

1965 History and settlement in Lower Nubia, Department of Anthropology, Yale University. New Haven.

1967 Settlement Archaeology. Its Goals and Promise, American Antiquity, 149-160.

Tung, T. A.

2008 Bioarchaeological Contributions to the Study of Migration and Diaspora Communities: Case Studies from the Central Andes in the Middle Horizon, en: H. Silverman y W. Isbell (eds.), Handbook of South American archaeology, 671-680, Springer Press, New York.

Uhle, $M$.

1922 Orígenes centroamericanos, Boletín de la Academia Nacional de Historia 4(9), 1-6.

Willey, G. R.

1953 Prehistoric settlement patterns in the Viru Valley, Peru, Bulletin 1, Bureau of American Ethnology, Washington, DC.

Young, K.

1990 Biogeography and ecology of a timberline forest in north-central Peru, tesis de doctorado, Universidad de Colorado, Boulder.

1993 National park protection in relation to the ecological zonation of a neighboring human community: An example from northern Peru, Mountain Research and Development 13 (3), 267-280.

Young, K.R. y B. León

1995 Distribution and conservation of Peru's montane forests: interactions between the biota and human society. En Tropical montane cloud forests, L S. Hamilton, J. O. Juvik, y F. N. Scatena (eds), 363-376, Springer, New York. 
